\title{
Geologically controlled sandy beaches: Their geomorphology, morphodynamics and classification
}

Shari L. Gallop, David M. Kennedy, Carlos Loureiro, Larissa A. Naylor, Juan J. Muñoz-

Perez, Derek W.T. Jackson, Thomas E. Fellowes

Published in:

Science of the Total Environment

Volume 731, August 2020, 139123

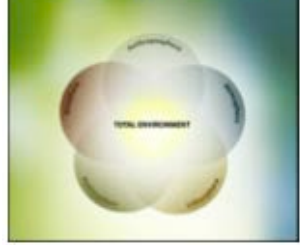

DOI: 10.1016/j.scitotenv.2020.139123

URL: https://www.sciencedirect.com/science/article/pii/S0048969720326401

Science of the Total Environment 731 (2020) 139123

Contents lists available at ScienceDirect

Science of the Total Environment

journal homepage: www.elsevier.com/locate/scitotenv

Review

Geologically controlled sandy beaches: Their geomorphology, morphodynamics and classification

Shari L. Gallop ${ }^{\text {a,b,* }}$, David M. Kennedy ${ }^{c}$, Carlos Loureiro ${ }^{\text {d,e }}$, Larissa A. Naylor ${ }^{f}$, Juan J. Muñoz-Pérez ${ }^{g}$, Derek W.T. Jackson ${ }^{\mathrm{h}}$, Thomas E. Fellowes ${ }^{\mathrm{i}, \mathrm{j}}$

a School of Science, University of Waikato, Tauranga 3110, New Zealand

${ }^{b}$ Environmental Research Institute, University of Waikato, Hamilton 3240, New Zealand

' School of Geography, The University of Melbourne, Parkville 3010, VIC, Australia

d Biological and Environmental Sciences, Faculty of Natural Sciences, University of Stirling, Stirling FK9 4LA. United Kingdom

e Geological Sciences, School of Agricultural, Earth and Environmental Sciences, University of KwaZulu-Natal, Westville Campus, Durban 4000, South Africa

i School of Geographical and Earth Sciences, University of Glasgow, G12 80Q United Kingdom

g CASEM (Andalusian Centre for Maritime Studies), Universidad de Cadiz, 11510 Puerto Real, Spain

${ }^{\text {h }}$ School of Geography and Environmental Sciences, Ulster University, Cromore Road, Coleraine BT52 1SA, United Kingdom

Department of Earth and Environmental Sciences, Macquarie University, 2109, NSW, Australia

i Geocoastal Research Group, School of Geosciences, The University of Sydney, 2006, NSW, Australia

Accepted refereed manuscript of: Gallop SL, Kennedy DM, Loureiro C, Naylor LA, Muñoz-Pérez JJ, Jackson DWT \& Fellowes TE (2020) Geologically controlled sandy beaches: their geomorphology, morphodynamics and classification. Science of The Total Environment, 731, Art. No.: 139123.

https://doi.org/10.1016/i.scitotenv.2020.139123

(c) 2020, Elsevier. Licensed under the Creative Commons Attribution-NonCommercial-NoDerivatives

4.0 Internationa http://creativecommons.org/licenses/by-nc-nd/4.0/ 


\title{
Geologically controlled sandy beaches: Their geomorphology, morphodynamics and classification
}

\author{
Shari L. Gallop ${ }^{1,2}$ \\ David M. Kennedy ${ }^{3}$ \\ Carlos Loureiro ${ }^{4,5}$ \\ Larissa A. Naylor ${ }^{6}$ \\ Juan J. Muñoz-Pérez ${ }^{7}$ \\ Derek W.T. Jackson ${ }^{8}$ \\ Thomas E. Fellowes ${ }^{9,10}$
}

${ }^{1}$ School of Science, University of Waikato, Tauranga, 3110, New Zealand.

shari.gallop@waikato.ac.nz

${ }^{2}$ Environmental Research Institute, University of Waikato, Hamilton, 3240, New Zealand

${ }^{3}$ School of Geography, The University of Melbourne, Parkville, 3010, VIC, Australia. davidmk@unimelb.edu.au

${ }^{4}$ Biological and Environmental Sciences, Faculty of Natural Sciences, University of Stirling, Stirling, FK9 4LA, United Kingdom, carlos.loureiro@stir.ac.uk

${ }^{5}$ Geological Sciences, School of Agricultural, Earth and Environmental Sciences, University of KwaZulu-Natal, Westville Campus, Durban 4000, South Africa

${ }^{6}$ School of Geographical and Earth Sciences, University of Glasgow, G12 800, United Kingdom. Larissa.Naylor@glasgow.ac.uk 
${ }^{7}$ CASEM (Andalusian Centre for Maritime Studies), Universidad de Cadiz, 11510 Puerto Real, Spain. juanjose.munoz@uca.es

${ }^{8}$ School of Geography and Environmental Sciences, Ulster University, Cromore Road, Coleraine, BT52 1SA, United Kingdom, d.jackson@ulster.ac.uk

${ }^{9}$ Department of Earth and Environmental Sciences, Macquarie University, 2109, NSW, Australia, thomas.fellowes@sydney.edu.au

${ }^{10}$ Geocoastal Research Group, School of Geosciences, The University of Sydney, 2006, NSW, Australia

Full postal address of contact author: Shari Gallop, University of Waikato Coastal Marine Field Station, 3/58 Cross Road, Sulphur Point, 3110, Tauranga, New Zealand. 


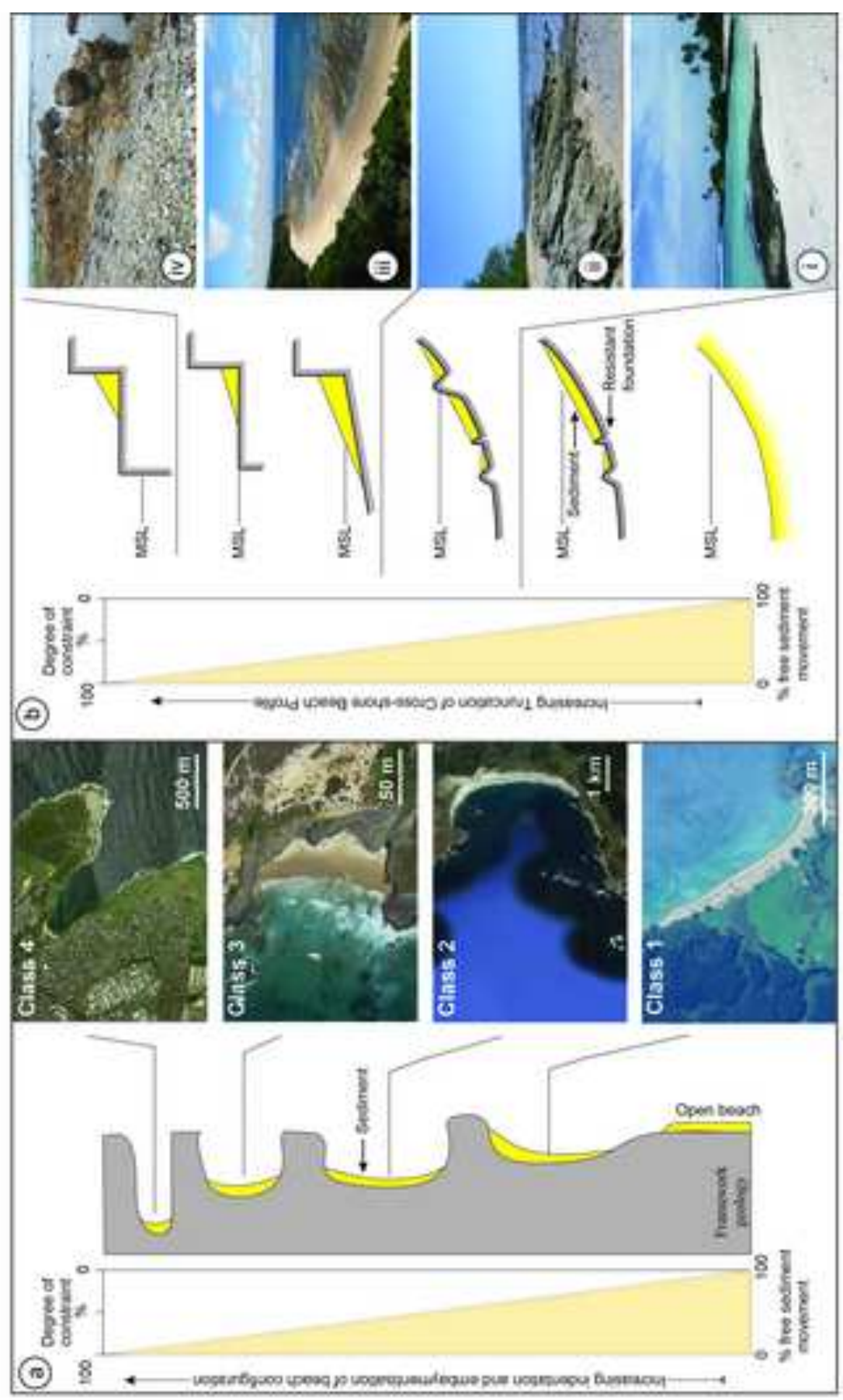


- Beaches geologically controlled by rock and coral formations are common globally.

- We review the state of knowledge of geological control of sandy beaches.

- There was no encompassing classification system for these beaches.

- We present longshore and cross-shore models from low to high geological control.

- There is poor applicability of models for management of this common beach type. 


\section{Abstract}

2 Beaches that are geologically controlled by rock and coral formations are the rule, not 3 the exception. This paper reviews current understanding of geologically controlled 4 beaches, bringing together a range of terminologies (including embayed beaches, 5 shore platform beaches, relict beaches, and perched beaches among others) and 6 processes, with the aim of exploring the multiple ways in which geology influences 7 beach morphology and morphodynamics. We show how in addition to sediment 8 supply, the basement geology influences where beaches will form by providing accommodation, and in the cross-shore, aspects of rock platform morphology such as elevation and slope are also important. Geologically controlled beaches can have significant variations in sediment coverage with seasons and storms, and geological controls have fundamental influences on their contemporary morphodynamics. This includes wave shadowing by headlands and rocky/coral formations inducing strong alongshore gradients in wave energy, resulting in corresponding variations in morphodynamic beach state and storm response. Geologically-induced rip currents such as shadow rips and deflection rips, and even mega-rips that can develop on embayed beaches during storms, are an integral feature of the nearshore circulation and morphodynamics of geologically controlled beaches. We bring these processes together by presenting a conceptual model of alongshore and cross-shore levels of geological control. In the longshore dimension, this ranges from beaches that are slightly embayed, through to highly embayed beaches where headlands dominate the entire beach morphodynamic response. In the cross-shore dimension, this ranges from beaches without discernible geological controls, through to relict beaches above the influence of the contemporary littoral zone. Given the prevalence of geologically controlled beaches along the world's coasts, it is paramount for coastal management to consider how these beaches differ from unconstrained beaches and avoid applying inappropriate models and tools, especially with our uncertain future climate. 
Keywords: Beach morphodynamics; shore platform; coral reef; headlands; perched beach; equilibrium profile

\section{Introduction}

Strong feedback loops exist within sandy beach systems, where a change in a single driver such as wave period and height, or sediment size, may result in an adjustment to beach form, whose interaction was termed morphodynamics by Wright and Thom (1977) and synthetized by Wright and Short (1984) for sandy beach environments. Most research on beach morphodynamics focuses on cross-shore and alongshore sediment exchange that is (at least assumed to be) unconstrained by geology or other hard substrates (Cowell and Thom, 1994; Short and Jackson, 2013; Feal-Pérez et al., 2014; Trenhaile, 2018). Classic examples include the beach change frameworks developed for single, double (Wright and Short, 1984; Wright et al., 1985) and multi-barred (Short and Aagaard, 1993) wavedominated beaches, and the model of Masselink and Short (1993) that accounts for tidal range using the Relative Tidal Range (RTR) parameter. In these models, the surf zone and beach morphology is essentially a function of grain size, wave and tide hydrodynamics, conveniently described through the surf scaling parameter, Dean's parameter and RTR (Jackson et al., 2005; Jackson and Cooper, 2009). However, many beaches have significant geological controls due to headlands, reefs, platforms, rock outcrops and islets (Short, 2006), which determine beach boundaries, beach morphology, morphodynamics and longterm evolution (Jackson et al., 2005; Gómez-Pujol et al., 2007; Short, 2010). An increasing number of studies show that beaches with geological controls have distinctly different behaviour compared to unconstrained beaches (González et al., 1999; Muñoz-Pérez et al., 1999; Jackson et al., 2005; Jackson and Cooper, 2009; Gallop et al., 2011b; Gallop et al., 2012, 2013; Loureiro et al., 2013; Gallop et al., 2015a; Trenhaile, 2016), which causes significant complications for coastal managers as traditional erosional models are not directly applicable in such settings. However, geologically controlled beaches are still largely not 
classified as a distinct type, there is still a fundamental lack of data on their behaviour, and there is no commonly-accepted terminology and classification system of their morphology.

Thus, the aims of this critical review are to understand our current state of knowledge on how geological control affects sandy beach morphology and morphodynamics, to identify key research needs and management implications of these understudied, globally distributed coastal systems. In Section 2 we review the terminology used for geologically controlled beach systems. Section 3 focuses on the morphodynamics of sandy geologically controlled beaches, starting with conditions necessary for beach accumulation in terms of the underlying geological surface morphology (Section 3.1), followed by a discussion of the sometimes stark temporal variations in sediment coverage that can occur in these systems (Section 3.2). This is followed by the analysis of how geological controls can reduce beach wave exposure, and also filter wave energy increasing the dominance of infragravity waves (Section 3.3). We then discuss the range of geologically controlled rip currents in Section 3.4 , followed by a summary of beach rotation in Section 3.5. Section 4 presents conceptual models of geological control in longshore directions (existing models) and in a cross-shore direction (a new model developed in this review). This is followed by conclusions in Section 6.

\section{Defining geologically controlled beaches}

Various terms have been applied in the geomorphological and engineering domains to describe geologically controlled beaches and their morphology (Table 1, Figure 1). The terms geologically controlled and geologically constrained have been used interchangeably, both to describe beaches with alongshore geological controls (Short, 2006, 2010) and/or where there is a geologically influenced cross-shore beach profile (Jackson and Cooper, 2009; Muñoz-Pérez and Medina, 2010). In particular, alongshore geological control is an important concept in delineating coastal sediment compartments (or cells) for coastal management (Gallop et al., 2015b), particularly where boundaries are located at rock 
80 headlands (Cooper and Pontee, 2006; Thom et al., 2018). It is a fundamental principle

81 behind the development of headland control as an engineering solution for coastal 82 stabilization (Silvester and Hsu, 1997).

83 In contrast, beaches without geological control in the cross-shore dimension, termed unconstrained by Jackson and Cooper (2009), have a sedimentary profile envelope that does not intersect or interact with the basement geology or semi-consolidated Quaternary lithologies (Jackson and Cooper, 2009) over contemporary morphodynamic time-scales. A typical example are the wave-dominated sandy beaches analysed in the classic Wright and Short (1984) morphodynamic model, where there is abundant sediment and the beach profile is assumed to adjust freely and fully to local hydrodynamic forcing by waves and tides (Jackson and Cooper, 2009). Some examples of geologically controlled beaches are given in Figure 1. While this paper focuses on hard substrates such as rock and coral, beach morphodynamics may also be influenced by other types of bioherms such as reefs built by gastropods, fan worms and molluscs such as oysters (Milliman, 1974; Piazza et al., 2005). Moreover, seagrass meadows (and associated litter) can also have a direct influence on the morphodynamics of geologically controlled beaches (Basterretxea et al., 2004; Gómez-Pujol et al., 2007; Aragonés et al., 2016) and may act in a similar way to a rock or coral reef

97 (Gómez-Pujol et al., 2011). These features are an important consideration in the management of many geologically controlled beaches but are beyond the scope of this paper. 

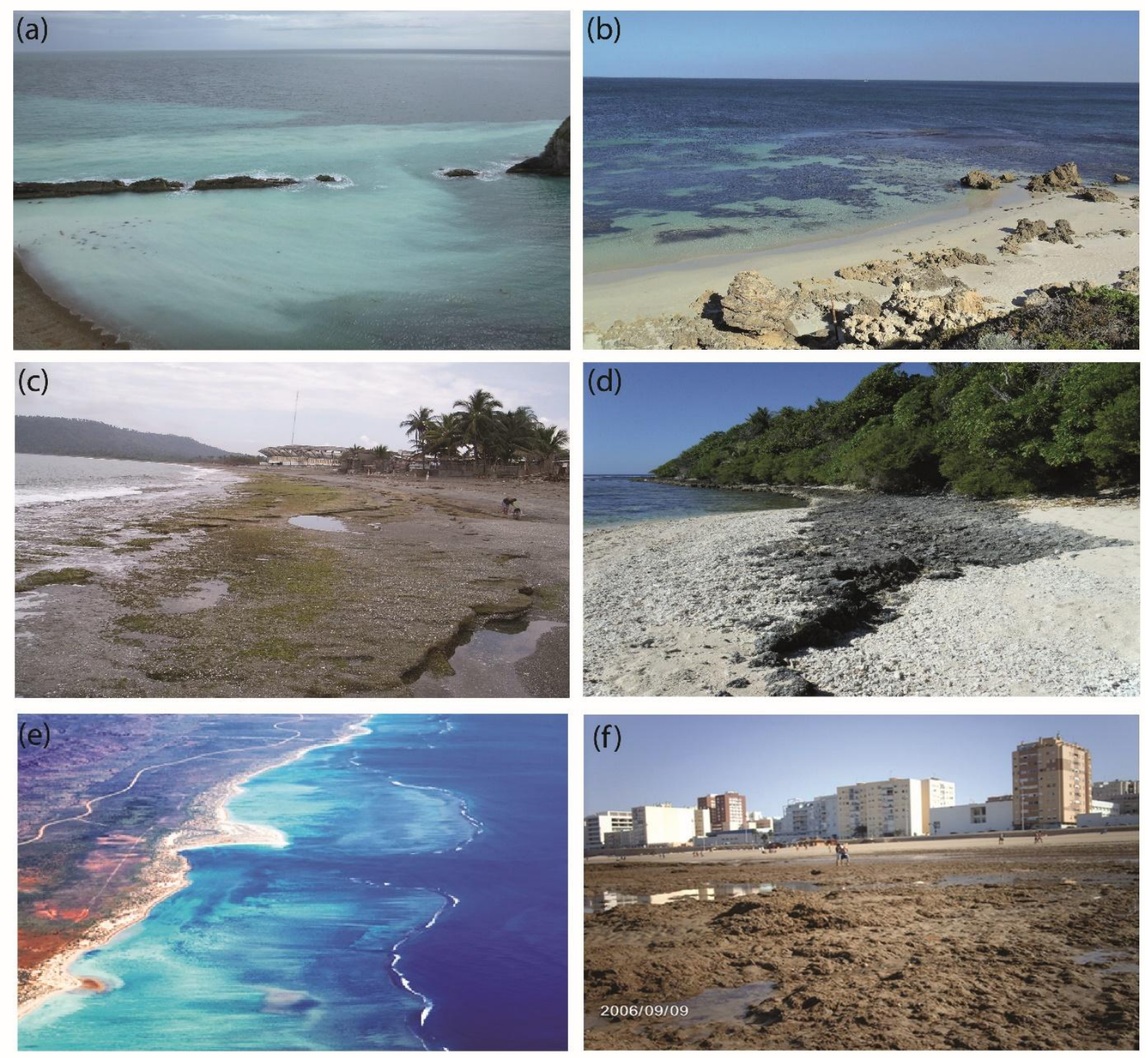

101 Figure 1. Examples of geologically controlled beaches: (a) sandy embayed beach on rock 102 reef at Man O'War Bay, Dorset, England (Photo: S.L. Gallop); (b) Sandy beach on rock pavement and intertidal outcrops at Rottnest Island, Western Australia (Photo: S. L. Gallop);

(c) Sandy beach behind intertidal rock platform in Cuba (Photo: M.I. Vousdouskas); (d)

Sandy pocket beach and beach rock platform at Motu Tuamotu, French Polynesia (Photo:

S. Bauer); and (f) Sandy beach on calcareous sandstone platform at Victoria Beach, Cadiz, SW Spain (Photo: J.J. Muñoz-Pérez). 
109 Other key terms in the literature describe sub-types of geologically controlled beaches. This

110 includes beaches constrained by beach rock formed by in situ cementation (Russell, 1959;

111 Cooper, 1991; Vousdoukas et al., 2007; Vousdoukas et al., 2009; Vousdoukas et al., 2012),

112 typically in the intertidal zone of tropical/subtropical and low latitude microtidal coasts

113 (Vousdoukas et al., 2007). On some beaches, geological control occurs due to submerged

114 or emergent (elevated about MSL) rock or coral reefs (Muñoz-Pérez et al., 1999; Sanderson,

115 2000), which may be naturally-occurring or artificial predominantly for coastal protection

116 (Ranasinghe et al., 2006). Beaches on top of shore platforms, or platform beaches (Taborda

117 and Ribeiro, 2015), are also subjected to strong geological controls (Stephenson, 2000;

118 Short, 2006; Trenhaile, 2016). The term 'hard bottom' has often been used in the literature to

119 describe rock outcrops (whether natural or engineered) on the beach and shoreface (Cleary

120 et al., 1996; Larson and Kraus, 2000; Hanson and Militello, 2005)

121 Of relevance in the context of geological control are also raised/stranded/relict beaches, although these terms are also applied to unconstrained beaches. For a beach to become relict, a change in base level is required to strand the beach above the reach of modern marine processes, which can be eustatically, glacio-isostatically or tectonically driven (Blackburn et al., 1967; Kidson and Wood, 1974; Sprigg, 1979; Huntley et al., 1993; Alonso and Pagés, 2007; Benedetti et al., 2009; Trenhaile, 2016). Raised beaches are particularly common in tectonically active areas where instantaneous base level change strands beaches so that they can no longer be reworked by contemporary marine processes, such as Turakirae Head (McSaveney et al., 2006) and Wellington (Olson et al., 2012) in New Zealand and Kujikuri, Japan (Tamura et al., 2008).

Some geologically controlled beaches are described as 'perched beaches' with various definitions of 'perched' existing from both the geomorphological and engineering literature. In the 1960's, the concept of engineered perched beaches was introduced by Inman and 134 Frautschy (1966), who explored the idea that an artificially-steep beach (often due to sediment nourishment) could be maintained if it was 'perched' on an engineered submerged 
dike. The inspiration for this design was based on observations in nature at Algodones in the

137 Gulf of California where the presence of a natural sedimentary rock outcrop $\sim 2.75 \mathrm{~m}$ below MSL enabled a wider beach than on the neighbouring coast (Moreno et al., 2018). Nowadays, in coastal engineering, the term 'perched' beach is typically defined as a beach or wedge of sand retained above the otherwise normal profile level by a submerged dike (US Army Corps of Engineers, 1984) (Figure 2). According to this definition, perched beaches are essentially an engineered raised beach with an artificial cross-shore geological control that aims to prevent offshore leakage of sediment.

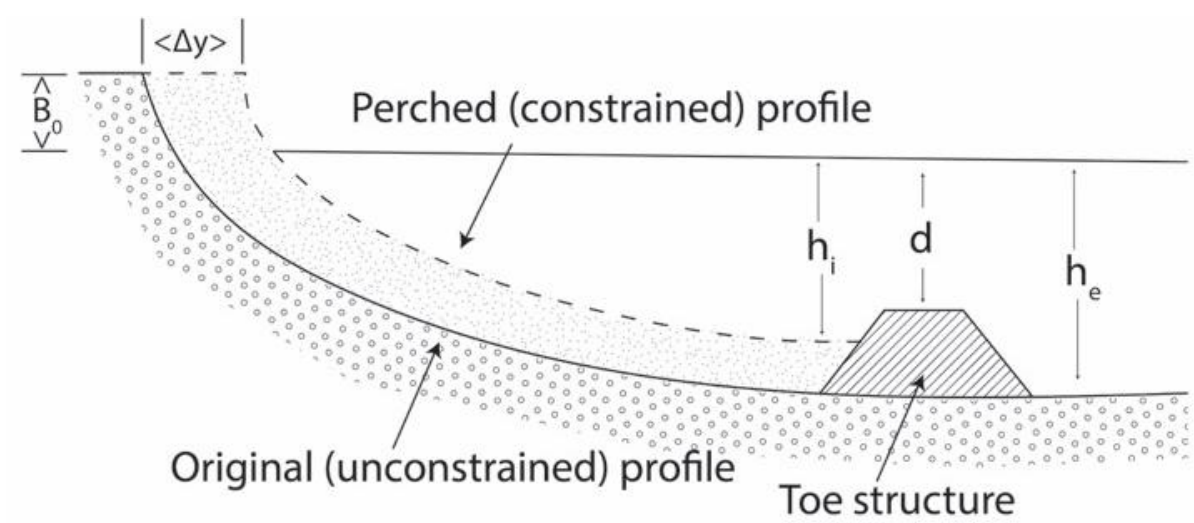

Figure 2. Schematic of an engineered perched beach (based on (González et al., 1999), where the main variables are indicated including (d) water depth over the toe structure (e.g., breakwater), water depth on the shoreward $\left(h_{i}\right)$ and seaward sides $\left(h_{e}\right)$ of the structure, the change in beach width $(\Delta y)$ and berm height $\left(B_{0}\right)$.

In a geomorphological context, the term 'perched beach' is sometimes used more broadly to describe beaches and other coastal landforms such as beach-barrier sequences (Pilkey et al., 1993; Riggs et al., 1995; Cleary et al., 1996), which have a hard substrate (e.g. rock or coral substrates) outcropping on the beach profile (Alexandrakis et al., 2013). The term perched beach has also been applied to beaches on shore platforms (Cleary et al., 1996), including those made of relatively soft, erodible materials such as soft mudstone and soft clay (Walkden and Hall, 2005) when the underlying and beach materials differ and there is limited exchange of sediment between the units (Shand et al., 2013). To avoid confusion 
between engineering and geomorphological terminology, we suggest that 'geologically controlled' is more appropriate than 'perched' to collectively describe beaches with crossshore geological constraints. The geology in our definition can be both artificial and engineered and refers to substrate which is more resistant to erosion than the overlying unconsolidated beach sand.

Table 1. Summary of terms used to describe types of geologically controlled beaches.

\begin{tabular}{|c|c|}
\hline Term & Definition \\
\hline $\begin{array}{l}\text { Geologically } \\
\text { controlled/constrained } \\
\text { beach }\end{array}$ & $\begin{array}{l}\text { Beach where the physical boundaries such as headlands, outcrops, reefs, } \\
\text { shore platforms and islets (Short, 2006) determine beach boundaries } \\
\text { (accommodation space), sediment supply, nature of sediments and } \\
\text { morphological change (McNinch, 2004; Jackson et al., 2005). Geology may } \\
\text { also intrude into the cross-shore idealised equilibrium beach profile envelope } \\
\text { (Jackson et al., 2005; Short, 2010). }\end{array}$ \\
\hline Unconstrained/open beach & $\begin{array}{l}\text { Beach where the sedimentary profile does not intersect or interact with the } \\
\text { basement geology or semi-consolidated lithologies (Jackson and Cooper, 2009) } \\
\text { over decadal time-scales. Beach can adjust freely to local hydrodynamic forcing } \\
\text { by waves and tides (Jackson and Cooper, 2009). }\end{array}$ \\
\hline $\begin{array}{l}\text { Embayed/pocket/crenulated } \\
\text { /headland-bay beach }\end{array}$ & $\begin{array}{l}\text { Beach bound laterally in one or both extremities by physical barriers such as } \\
\text { headlands, rock platforms or artificial structures such as groins, jetties and } \\
\text { breakwaters (Hsu and Evans, 1989; Fellowes et al., 2019). }\end{array}$ \\
\hline $\begin{array}{l}\text { Reef-protected } \\
\text { beaches/beaches with } \\
\text { submerged structures such } \\
\text { as breakwaters }\end{array}$ & $\begin{array}{l}\text { Beaches with natural or artificial submerged or emergent (elevated about MSL) } \\
\text { rock or coral reefs (Muñoz-Pérez et al., 1999; Sanderson, 2000; Moschella et } \\
\text { al., 2005), or lithified submerged barriers/ paleo shorelines in the nearshore } \\
\text { (McNinch, 2004; Gómez-Pujol et al., 2019). See Ranasinghe et al. (2006) for a } \\
\text { review of shoreline response to nearshore submerged structures. }\end{array}$ \\
\hline
\end{tabular}




\begin{tabular}{|c|c|}
\hline Shore platform beaches & $\begin{array}{l}\text { Beaches where the underlying beach substrate is an erosional rocky shore } \\
\text { platform. These beaches occur above MLWS elevation (Stephenson, 2000; } \\
\text { Trenhaile, 2004; Doucette, 2009; Kennedy and Milkins, 2015). }\end{array}$ \\
\hline $\begin{array}{l}\text { Relict/raised/stranded } \\
\text { beach }\end{array}$ & $\begin{array}{l}\text { Beach that is elevated well-above current MSL and even extreme storm } \\
\text { conditions, as a result of eustatically, glacio-isostatically or tectonically driven } \\
\text { change in base level (Blackburn et al., 1967; Kidson and Wood, 1974; Sprigg, } \\
\text { 1979; Huntley et al., 1993; Alonso and Pagés, 2007; Benedetti et al., 2009; } \\
\text { Trenhaile, 2016). These terms can be applied to geologically controlled and } \\
\text { unconstrained beaches alike. }\end{array}$ \\
\hline Perched beach & $\begin{array}{l}\text { Engineering: "a beach or wedge of sand retained above the otherwise normal } \\
\text { profile level by a submerged dike" (US Army Corps of Engineers, 1984) } \\
\text { Geomorphology: broad term describing beaches with either a hard substrate } \\
\text { outcropping on the beach profile such as submerged beach rock and coral } \\
\text { reefs (Gallop et al., } 2011 \text { b; Gallop et al., 2012; Alexandrakis et al., 2013; Gallop } \\
\text { et al., 2013) or where material underlying the beach has a different } \\
\text { composition, such as soft clay (Walkden and Hall, 2005). }\end{array}$ \\
\hline
\end{tabular}

163 It is important to consider that geological beach control will occur in any situation where 164 bedrock is outcropping on the beach profile. As a result, it is more likely to occur in areas of 165 high coastal relief and in instances where there is restricted sediment supply (Cooper et al., 2018). Changes to sediment supply which would lead to a reduction in total beach volume could potentially shift beaches from being unconstrained to geologically controlled as bedrock becomes exposed (Masselink et al., 2016) (discussed further in Section 3.2). Globally, this may become more common as sediment supply to the coast is reduced 170 (Syvitski et al., 2005), however, exploration of this topic is beyond the scope of this study. 


\subsection{Beach accumulation on shore platforms}

175 Beaches that develop through sand accumulation on shore platforms are probably the most well-studied form of cross-shore geologically controlled beach (Trenhaile, 2016). On shore platform beaches, a rocky surface occupies at least part of the intertidal zone. The degree to which sediment can accumulate, and therefore the level of beach profile development, is a product of the elevation of the platform and its slope (Trenhaile, 2004; Kennedy and Milkins, 2015). Trenhaile (2004) modelled the accumulation of beach sediment on shore platforms and found that sediment will only accumulate when the slope of the platform is less than the slope of the beach. This is because a higher platform angle will favour offshore rather than onshore sediment transport. If the platform gradient is low enough, beach development initiates at the cliff base and extends seaward if sediment is available. If the platform is sloping, the beach can only develop on sections of the platform with a gradient less than the equilibrium beach face gradient, which depends on breaker height, wave period and sediment grain size (Sunamura, 1989). This relationship of beach development and platform slope means that the sub-horizontal platforms found in micro- and lower meso-tidal ranges are particularly conducive to beach formation (Trenhaile, 2004). Beaches are also more likely to develop on the lower-gradient regions of convex platforms (seaward end) and concave platforms (landward end). In addition, platform gradient has an influence on the sediment grain size that can accumulate to form the beach, where smaller grain sizes can build up on more gently-sloping platforms, compared to larger grain sizes on steeper platforms. Trenhaile (2004) also suggested that only pebbles and other coarse material can accumulate on platforms with a gradient of more than $5^{\circ}$, and coarse sand can accumulate when the platform gradient is between $2^{\circ}$ and $5^{\circ}$. important (Trenhaile and Layzell, 1981), which implies that the potential for platform beach 
199 formation is higher on microtidal rocky coasts. In such low tide range settings in Victoria, SE

200 Australia, Kennedy and Milkins (2015) found that shore platform elevation was a critical

201

202

203

204

205

206

207

208

209

210

211

212 determinant of beach accumulation. Sand was only able to accumulate when the platform dropped below the combined elevation of the mean annual wave height and the Mean High Water Springs (MHWS) tide level. Once sand could accumulate on the shore, the width of the platform then became a significant factor in determining beach volume. Wider platforms dissipate more wave energy (Trenhaile, 2005; Marshall and Stephenson, 2011) and therefore encourage sediment deposition. In SE Victoria, there was a positive relationship between platform width and beach volume once the platform was low enough for sediment to accumulate (Kennedy and Milkins, 2015). In this region, at Cape Paterson (Figure 5iii), where a wide platform at low tide elevation is found, a steep beachface with cusps developed, however in Lorne, where the platform is at MSL and has half the width of the previous case, only a featureless upper beachface is present.

In some predominantly rocky settings, such as on highly embayed coasts, beach morphology may be more a function of the longshore dimensions of the embayments in which they are formed rather than solely the platform elevation and width (Bowman et al., 2009). For example, in Niue in the South Pacific Ocean the beaches sit at the rear of wide shore platforms at intertidal elevations, but are ephemeral, disappearing during tropical cyclones, and during non-storm periods only the low intertidal parts of the profile can form. Their morphology is therefore limited by the accommodation space. That is, in addition to being vertically geologically constrained, their high intertidal and supratidal profile cannot form due to the presence of vertical cliffs which limit lateral accommodation space.

\subsection{Temporal variation in sediment coverage}

On geologically controlled beaches, there is a paucity of empirical data on spatial and temporal changes compared to studies of unconstrained beaches (Fox and Davis, 1978; Davidson-Arnott and Law, 1996; Masselink et al., 2016). Yet, the limited observations show 
that there can be dramatic temporal changes in sediment coverage and thickness over the geological substrate. For example, during the extreme 2013-14 winter storms in SW England, large quantities of sand moved offshore (Masselink et al., 2016), revealing the underlying rocky substrate. Such behaviour can also occur on a regular basis over seasonal time-scales, such as on a beach overlying a calcarenite limestone platform near Perth, WA, where in winter, the sub-horizontal platform can be exposed, and then recovered with sediment during summer (Doucette, 2009). An example is shown in Figure 3 of Yanchep, WA, which also undergoes dramatic seasonal changes in sediment coverage and thickness (Gallop et al., 2013). There have been few studies comparing rates of erosion and accretion of geologically controlled compared to unconstrained beaches. Muñoz-Pérez and Medina (2010) found that the accretion rate was much faster on an unconstrained, sandy beach profile, compared to a profile geologically-constrained by a rock reef $\left(1.01 \mathrm{~m}^{3}\right.$ day $^{-1}$ compared to $0.33 \mathrm{~m}^{3}$ day $^{-1}$ ) in Cadiz, SW Spain. The relatively slower rates of recovery of geologically controlled beaches may relate partly to the ability of sediment to be transported above the seaward terminus of the rock/coral substrate and onto the beach. In microtidal environments this seaward edge can range in shape from a gently sloping ramp to vertical cliff (Kennedy, 2015, 2016), and when steep it can prevent onshore sediment movement during calm conditions (Trenhaile, 2004). Bosserelle et al. (2011) reported that the presence of a sand ramp fronting a rock reef was crucial to allow sediment to overtop the reef onto the beach. This can increase the time it takes for beaches on platforms/reefs with abrupt seaward terminuses to recover after erosive events and periods, as very specific and relatively infrequent hydrodynamic conditions that combine moderately energetic constructive waves and larger tidal ranges are required for subtidal sediments to be entrained and transported onshore. 

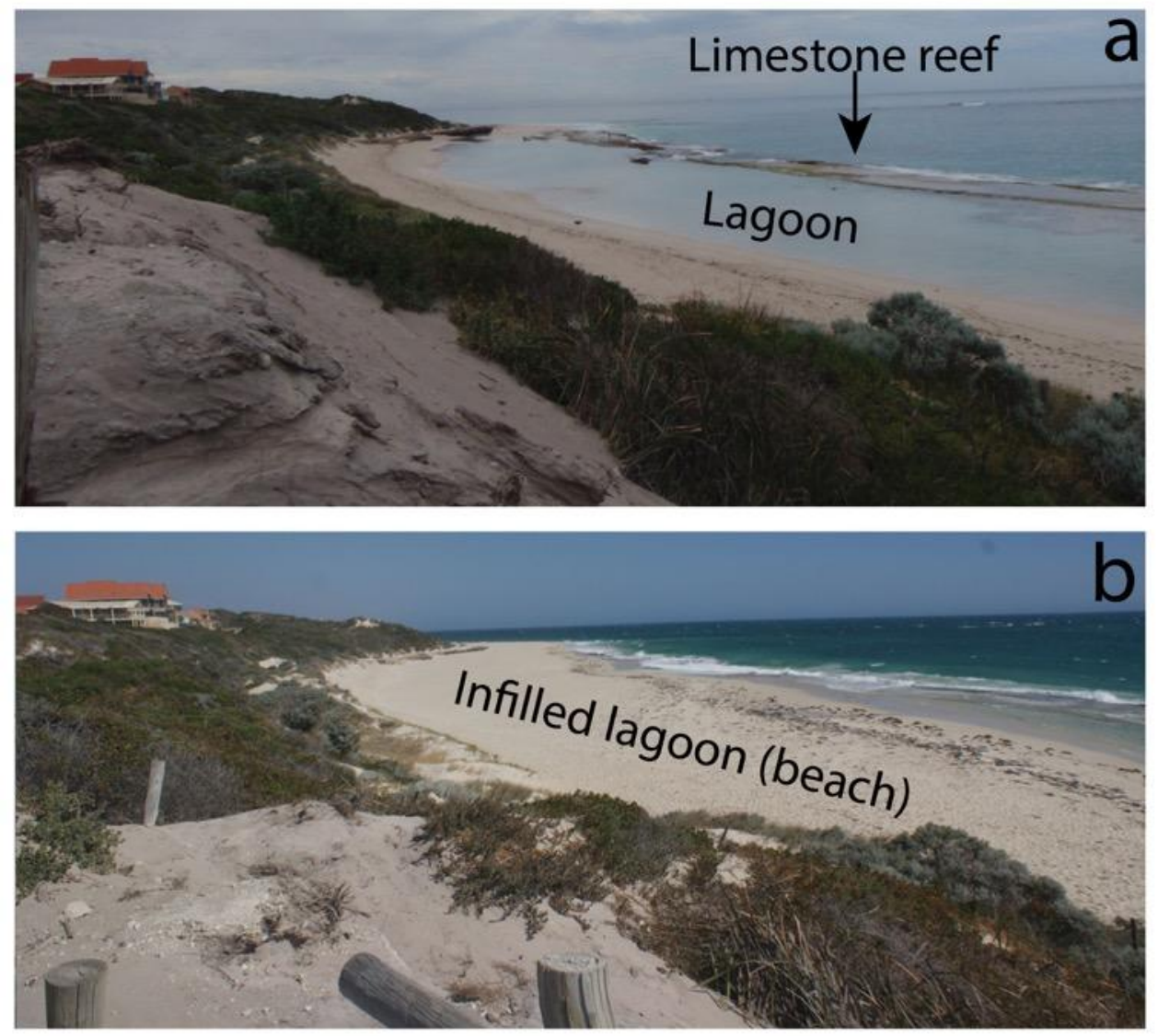

250 Figure 3. Example of large differences in seasonal sediment accumulation at Yanchep,

251 Western Australia, where the beach is fronted by calcarenite limestone reef. (a) is the winter

252 (eroded) state; and (b) the summer (accreted) state. (Photos: C. Bosserelle). Volume

253 changes of up to $1.13 \mathrm{~m}^{3} / \mathrm{m}$ between summer and winter have been measured here, leading

254 to a total seasonal change of up to $93,970 \mathrm{~m}^{3}$ over this $600 \mathrm{~m}$ long beach (Gallop et al., 255 2013).

256 On some types of geologically controlled beaches, such as those on seaward sloping 257 platforms, a reduced capacity for sediment storage (Trenhaile, 2004) may allow only the development of a thin, veneer beach in months with more quiescent wave conditions, which can be easily eroded in winter to expose the platform. For example, in South Wales, UK, calmer, more southerly and shorter-fetch summer winds and waves transport sand onto the shore platforms, which are then typically removed during winter storms where longer-fetch south westerly waves dominate (Naylor et al., 2016). This trend is most evident in the lower 
263 intertidal zone where sand accumulation is highest (Figure 4). Nine months of bi-monthly 264 cross-shore monitoring of sand percentage cover (as the accumulations are very thin, 265 typically less than 1-2 cm thick) data were collected from 26 systematically randomly placed $2661 \mathrm{~m}^{2}$ quadrats across the intertidal zone (Figure 4). Sand accumulations varied across this 267 platform where the presence of sand was strongly modulated by: (1) shore position (with the 268 upper intertidal zone having considerably less sand accumulation than lower down the 269 shore); (2) surface morphology, as more sand accumulated in depressions; and (3) biology, 270 where macroalgae helped retain sediment (Figure 4). It is important to note that these 271 seasonal modulations of sand allow the polychaete worm, Sabellaria alveolata, to establish 272 large communities on these shore platforms, as the species requires the presence of sand to 273 grow the tubes which provide their habitat and a hard substratum on which to affix 274 themselves to establish their colonies (Naylor and Viles, 2000). 


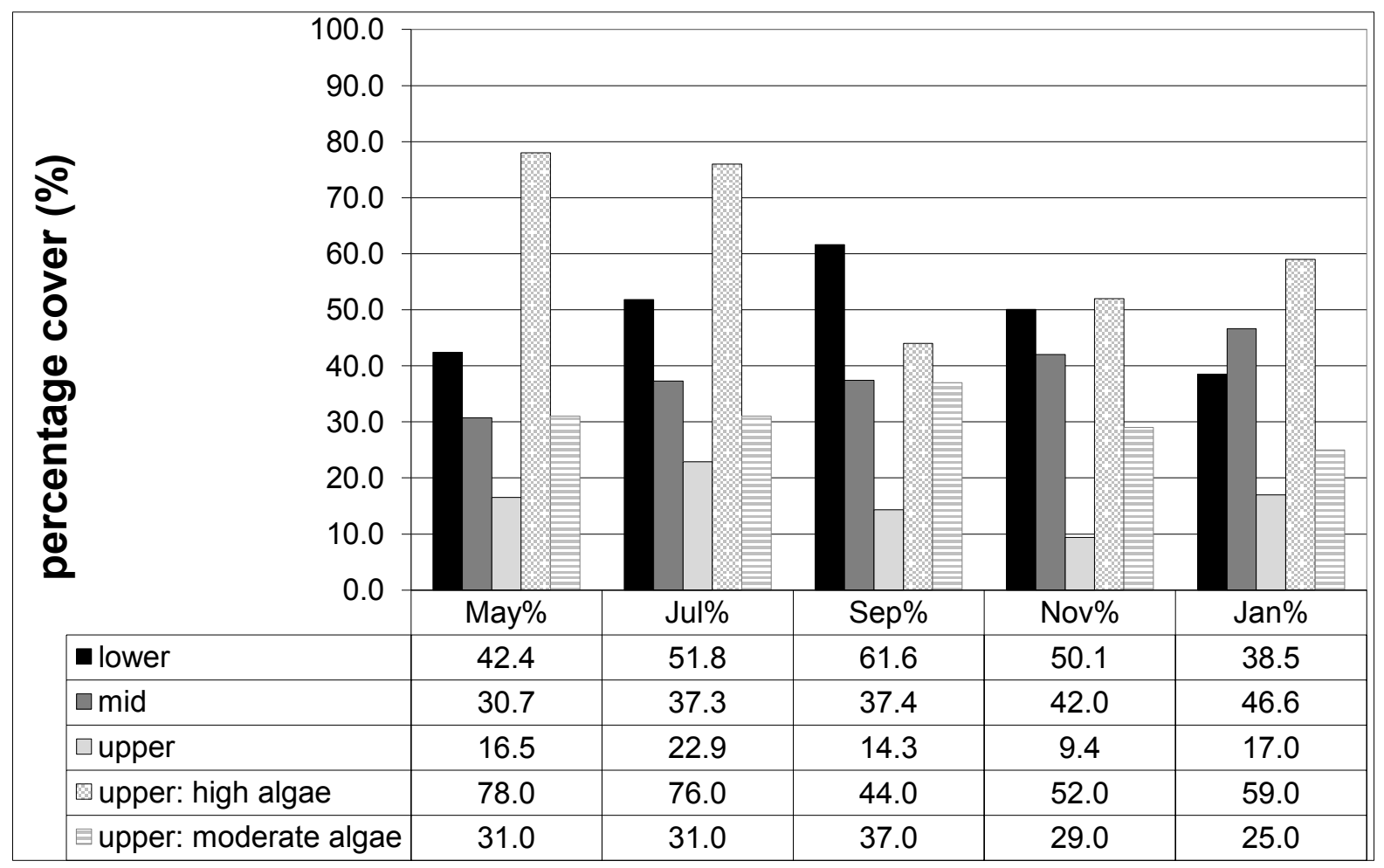

Figure 4. Spatial and temporal variations in the percentage cover of ephemeral sand accumulations on a rocky shore platform in South Wales, UK over a 9-month period between May 1999 and January 2000. (Source: data adapted from Naylor (2001)).

\subsection{Geologically controlled reduction in wave exposure}

On any given beach, the amount of incident wave energy that reaches the shore (wave exposure) and it's alongshore variability is integral to the beach morphology and behaviour.

Geological features can have a significant influence on the wave exposure of a beach, where features such as headlands can result in wave shadowing in their lee (Daly et al., 2014), which creates an alongshore gradient in wave energy and concurrent variations in the beach morphology and behaviour (Castelle and Coco, 2012; McCarroll et al., 2014). In addition, other wave dissipation processes such as wave breaking and bottom friction can also be amplified on geologically controlled beaches. For example, besides the relatively shallow nature of some engineered rock structures and rock/ coral reefs that induce wave breaking due to depth limitation (Frihy et al., 2004; Gallop et al., 2012), the roughness of rocks and reefs can increase wave dissipation through bottom friction (Rey et al., 2004; Ford 
et al., 2013; Ruiz de Alegria-Arzaburu et al., 2013), theree reducing wave exposure and

291 beach erosion (Dickinson, 1999; Frihy et al., 2004). On Kaanapali Beach, Maui, for example,

292 the shallow ( $<1 \mathrm{~m}$ deep) fringing coral reef promotes beach stability by reducing rates of longshore sediment transport and increasing wave dissipation (Eversole and Fletcher, 2003). At Yucatan Peninsula (SE Mexico), the landfall of category 4 hurricane Wilma in 2005 caused widespread erosion of an unconstrained beach at Cancun, while $25 \mathrm{~km}$ south a geologically controlled beach with a fringing coral reef accreted due to wave and current dampening in the lee of the reef (Mariño-Tapia et al., 2014; Mulcahy et al., 2016). It is also important to consider that the nearshore submarine geology can also influence shoaling processes and ultimately local beach morphodynamics (Gómez-Pujol et al., 2019), similar to the reefs and submerged engineering structures described previously. For example, the presence of paleo-channel/ sub-marine canyons (Jacob et al., 2009) can result in alongshore gradients in wave energy through impacts on wave refraction and dissipation and can also lead to rip currents (Long and Özkan-Haller, 2005).

Significant amounts of wave energy may still propagate through submerged coastal structures such as reefs, due to low-frequency fluctuations, and if resonant conditions occur (Karunarathna and Tanimoto, 1995). These low-frequency oscillations can occur due to nonlinearities in the short wave field, and include bound and free long waves (Karunarathna and Tanimoto, 1995; Payo and Muñoz-Perez, 2013). Moreover, measurements indicate that the energy spectrum on coral reef flats is dominated by infragravity frequencies (Young, 1989; Brander et al., 2004; Winter et al., 2017), and reef topography can lead to excitation of resonant modes (Péquignet et al., 2009), such as by wave groups (Gallop et al., 2012). In addition, on beaches resting on platforms, the frequency of waves is altered as they propagate across the platforms, with wave breaking filtering out gravity waves and increasing infragravity wave height (Beetham and Kench, 2011; Ogawa et al., 2012). Thus, while submerged rock substrates supporting beaches can dissipate waves, significant amounts of wave energy can still impact the shoreline during particular topographic and 
317 forcing conditions. It was demonstrated by Winter et al. (2017) that cross-shore standing

318 water elevation patterns can be generated by infragravity waves, even in environments with

319 highly irregular alongshore bathymetry such as coral reefs; and refraction of infragravity waves by nearshore reefs can also propagate in opposite alongshore direction causing a local standing wave pattern.

\subsection{Geologically controlled rip currents}

Rip currents are commonplace on wave-dominated beaches and play a key role in sediment transport, surf zone circulation, and beach morphodynamics (Wright and Short, 1984; Gallop et al., 2018). There are three broad categories of rip currents, all of which can be present on geologically controlled beaches. As outlined in the recent review by Castelle et al. (2016), the first two categories: (1) hydrodynamically controlled rip currents (flash rips and shear instability rips); and (2) bathymetrically controlled rip currents (channel rips and focused rips) are found on wave-dominated beaches with and without geological controls. Although geological controls can influence the spacing, dimensions and behaviour of these rip currents (Holman et al., 2006; Bryan et al., 2009; Gallop et al., 2011c; Castelle and Coco, 2012), they are not explored further here as their presence is not fundamentally dependent on geological controls. On the other hand, the presence of rip currents in the third category: (3) boundary controlled rip currents, is dependent on geological formations such as headlands (or engineered structures such as breakwaters that mimic these) that exert lateral controls on surf zone circulation (Alvarez-Ellacuria et al., 2009; Castelle et al., 2016). The two key types of boundary controlled rips are shadow rips and deflection rips, and they tend to be relatively permanent features. Shadow rips can form on beaches where an obstacle such as a headland, shadows (protects) part of the beach from obliquely-incident waves, resulting in an alongshore gradient in incident wave energy and driving an offshore-flowing

341 jet (rip current) against the boundary (Pattiaratchi et al., 2009; McCarroll et al., 2014). Deflection rips are formed when oblique waves drive strong alongshore currents that deflect 
seaward when reaching an obstacle such as a headland (Castelle and Coco, 2013; Scott et al., 2016).

Geological controls from rock or coral reefs and shore platforms can also result in current jets in cross-shore through to longshore directions, with rapid shifts between longshore to rip-dominated beach circulation dependent on wave direction and tidal stage (Horta et al., 2018). For example, rock and coral reefs (or breakwaters) exert an important control on wave breaking, which results in gradients in water level due to wave set-up and radiation stress, contributing to "piling" of water in the lee of a reef due to impeded return flow (Dean et al., 1997). This drives the development of longshore and rip currents (Dean et al., 1997; Gallop et al., 2011a; Gallop et al., 2011c; Taebi et al., 2011; Gallop et al., 2015a), which during storm events can both: (a) exacerbate erosion in areas where sediment is taken from; and (b) ultimately reduce erosion in areas where sediment transported by the current is deposited as a sand bar which then promotes wave breaking (Gallop et al., 2012).

On embayed beaches, embayment-cellular rips can also occur (Castelle et al., 2016), where a rigid boundary (e.g., headlands) can dominate the circulation of the embayment (Short and Masselink, 1999). These embayment-cellular rips are often topographically controlled and occur along headlands at one or both ends of an embayment depending on the boundary geological controls, waves and beach curvature (Castelle and Coco, 2012), or may also occur at the centre of larger embayed beaches (Short, 2007). Cellular circulation on embayed beaches is particularly relevant during storms, as it can drive the development of large, erosional rip current systems called mega-rips (Short, 1985, 2007; Loureiro et al., 2012a). Mega-rips is a broad term describing large $(>1 \mathrm{~km})$, strong rip currents flows that extend far beyond the surf zone that can play an important role in surf zone morphology and circulation even during post-storm low energy conditions (Short, 1985; McCarroll et al., 2014). Cellular rip current flows in embayed beaches tend to scale positively with increasing wave height and decreasing embayment size (Short and Masselink, 1999). Megarips can cause severe surf zone and beach and dune erosion during storms (Short and Hesp, 1982), 
particularly when the mega-rip and feeder channels persist over successive storms

371 promoting continued erosion and hindering beach recovery (Loureiro et al., 2012a)

\subsection{Beach rotation}

373

Due to the inherent alongshore compartmentalisation and exposure to temporal and spatially variable wave conditions, beach rotation is a common phenomenon on geologically controlled beaches (Gallop et al., 2013; Habel et al., 2016; Trenhaile, 2016). Beach rotation can be defined as the alternating morphological response of opposite sections of an embayed beach, driven by cross-shore and/or longshore morphodynamic processes or their interaction, coupling the beach and nearshore in response to changes in hydrodynamic forcing (Loureiro and Ferreira, 2020). Beach rotation occurs mainly through alongshore and/or cross-shore non-uniform sediment transport due to variation in wave direction and/or gradients in wave energy (Harley et al., 2011; Harley et al., 2015), but can also be driven by cellular circulation mechanisms (Loureiro et al., 2012b). While beach rotation is an embayment-wide morphological response on geologically constrained beaches, the precise mechanisms and drivers of beach rotation are often characterized by interacting and complementary morphodynamic processes (Muñoz-Pérez et al., 2001; Harley et al., 2015; Blossier et al., 2017). Loureiro and Ferreira (2020) distinguish beach rotation as: (1) an alongshore coherent response to reversals in wave direction, when sediment transported alongshore accumulates against a geological boundary (e.g. headland, reef, engineered structure), while the opposing section erodes and thus the beach appears to rotate, usually around a pivotal point or transition zone (Antonio Henrique da Fontoura et al., 2002); (2) the result of combined cross-shore and longshore morphological response to variability in wave forcing, as detailed in Harley et al. (2015); and (3) beach rotation as the planform expression of changes in nearshore morphological dynamics and cellular circulation. 
rotation driven by interannual to decadal climate-forced changes in wave climate

397 (Ranasinghe et al., 2004). In the medium-term (months to a year), beach rotation is associated mainly with seasonal changes in incident wave characteristics (Turki et al., 2013; Habel et al., 2016), which can be particularly pronounced in regions that experience a bidirectional wave climate. This distinction between mechanisms and timescales does not necessarily mean that beach rotation at any given beach takes place always in the same timescale or through exact the same morphodynamic mechanisms (Loureiro and Ferreira, 2020). Overlapping or interacting timescales and processes are frequently observed, particularly in cases where quick rotation towards one end of the embayment is driven by storm events, while the rotation in the reverse direction takes place as slower, posts-storm recovery, often lagging the changes in hydrodynamic forcing (Ranasinghe et al., 2004).

On beaches that experience variable cross-shore geological control, mainly due to the differences in the alongshore configuration of rock outcrops, seasonal beach rotation can occur in response to non-uniform oscillation of the cross-shore beach profile (Muñoz-Pérez et al., 2001). Alongshore variability in nearshore reef configuration also contributes to rotational responses of geologically controlled beaches, particularly when seasonal infilling of the nearshore area between the reef and the beach inhibits alongshore sediment transport, resulting in downdrift erosion. Conversely, when this sediment is eroded due to winter storms, sediment can then nourish the downdrift beach such as evidenced at Yanchep Lagoon, Western Australia (Gallop et al., 2013).

Beach rotation can lead to changes in shoreline position in the order of tens of meters (Short and Trembanis, 2004), but in most cases sediment is assumed to remain within the embayment, implying no net changes in the overall sediment budget. While this assumption is valid for most cases and geologically controlled beaches are closed sediment system cells

420 or compartments, the accumulation of sediment towards one end of an embayment combined with headland sediment bypassing can lead to significant sediment losses. In such cases beach rotation becomes a fundamental mechanism for sediment connectivity, 
423 contributing to a shift of geologically controlled beaches from closed to leaky compartments

424 (Thom et al., 2018).

\section{Models of geological control}

Beach-state classifications and conceptual models provide a framework for understanding the beach environment by distinguishing beaches through the morphology of the depositional landforms and coupled morphodynamic processes (Wright and Short, 1984; Wright et al., 1985). In the sections below, we consider existing models and classifications for beaches with longshore and cross-shore geological control of beach morphodynamics, and build on these to systematise new conceptual models for geologically controlled beaches. For a more detailed analysis of accommodation space and first order geological controls for beaches/barriers see Cooper et al. (2018).

\subsection{Longshore geological control}

Many geologically controlled beaches are defined as embayed as they are bound laterally by physical boundaries such rocky headlands and platforms (Hsu and Evans, 1989). The length, spacing, planform and morphology of embayed beaches is significantly impacted by this pre-existing bedrock which provides the accommodation space (Short and Masselink, 1999; Cooper et al., 2018), so geological boundaries are a primary control on the morphodynamics of embayed beaches. The headlands on embayed beaches have diverse morphology, and may be symmetrical or asymmetrical in terms of their length, width, and orientation to the shoreline/wave approach (McCarroll et al., 2016; Fellowes et al., 2019). Embayed beach dimensions and headland length have an important influence on the level of geological control on the sediment budget and alongshore connectivity. Larger headlands promote sediment retention within the compartment while leaking or 'bypassing' of sediment is more likely for smaller headlands, especially combined with large waves coming from an oblique angle (George et al., 2019). This can result in embayed beaches being defined as 
'closed' if sediment is retained within the compartment, or 'leaky' if it can bypass headlands by littoral drift and be lost from the compartment (Thom, 1989; Thom et al., 2018).

450

451

452

In addition to providing the initial setting and accommodation space for a beach to form, the headlands of embayed beaches are also a fundamental driver of beach morphodynamics. This occurs through various processes, including wave shadowing which creates an alongshore wave energy gradient (discussed in Section 3.3), alongside geologically-induced wave refraction and dissipation (Loureiro et al., 2012a). As discussed in Section 3.4, headlands and the associated wave shadowing can result in the formation of boundary controlled rip currents (shadow rips and deflection rips) (Castelle et al., 2016), and, moreover, the embayment dimensions can also result in cellular circulation and the developed of mega-rips (Loureiro et al., 2012a). The length and orientation of headlands has an important influence on the afore-described processes, for example affecting the extent of wave shadowing and hence alongshore wave energy gradients, which dictate alongshore changes in morphodynamic beach state, surf zone width and rip channel dimensions (McCarroll et al., 2016). Whether or not headlands are symmetric is also important in terms of beach storm response, for example at the embayed Bondi Beach in Australia McCarroll et al. (2016) found that symmetrical headlands resulted in mega-rip formation at each headland, while asymmetric headlands may prevent this. In this case, the more protected end of the beach may remain in a low energy morphodynamic state such as low tide terrace, while the more exposed zone transitioned to a higher beach state such as from transverse bar and rip to a complex double bar, with a mega rip at the exposed headland (McCarroll et al., 2016). Thus, the morphology of headlands, particularly their length and orientation, is integral for defining the beach setting, whether the beach is a closed or leaky compartment, and the beach morphodynamics.

The recognition of the fundamental role of geological control has led to a progression of parametric equations to classify embayed beach planform and morphology. Hsu et al. (1989) developed the embayed beach planform ratio (based on the ratio of indentation of the 
475 embayment to width between headlands $\left(R_{o}\right)$, which can only be applied to embayed 476 beaches with a parabolic shape (Klein and Menezes, 2001). Short and Masselink (1999)

477 developed the non-dimensional embayment scaling factor $(\delta)$ which is calculated by:

$$
\delta=S_{l}^{2} / 100 R_{0} H_{b}
$$

478

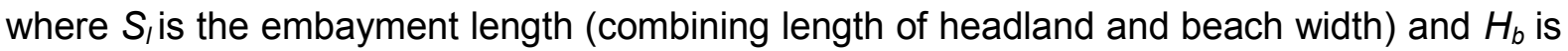
breaker wave height. $\delta$ is used to classify between the three key surf zone circulation patterns on embayed beaches as cellular $(\delta<8)$, transitional $(\delta=8-19)$, and normal $(\delta>19)$. Castelle and Coco (2012) built on this to explore in more detail the degree of headland impact on beach circulation by considering the ratio between embayment length $(L)$, surf zone slope $(\beta)$ and breaking wave height:

$$
\delta=\frac{L \gamma_{b} \beta}{H_{s}}
$$

where $\gamma_{b}$ is the breaking parameter and $H_{s}$ is significant wave height. Fellowes et al. (2019) later developed a new approach not requiring in situ data, as it could be applied through open-source imagery, which classified the degree of embaymentisation through the embayment morphometric parameter $\left(\gamma_{e}\right)$ calculated as:

$$
\gamma_{e}=a / \sqrt{A_{e}}
$$

Where $a$ is indentation of the embayment from the seaward end of the headland to landward back-beach limit, and $A_{e}$ is the embayment area within these limits. The degree of embaymentisation $\left(\gamma_{e}\right)$ is an indicator of the level of alongshore geological control on beach morphodynamics. Fellowes et al. (2019) applied $\gamma_{e}$ to 168 swell-dominated embayed beaches from 6 global regions, and using k-means clustering identified 4 classes of embayed beach, with $\gamma_{e}$ increasing with the degree of headland influence and impact on beach wave exposure. The classes ranged from 1 to 4 , with Class 1 being the least embayed, through to Class 4 which is the most embayed. These classes are represented in 

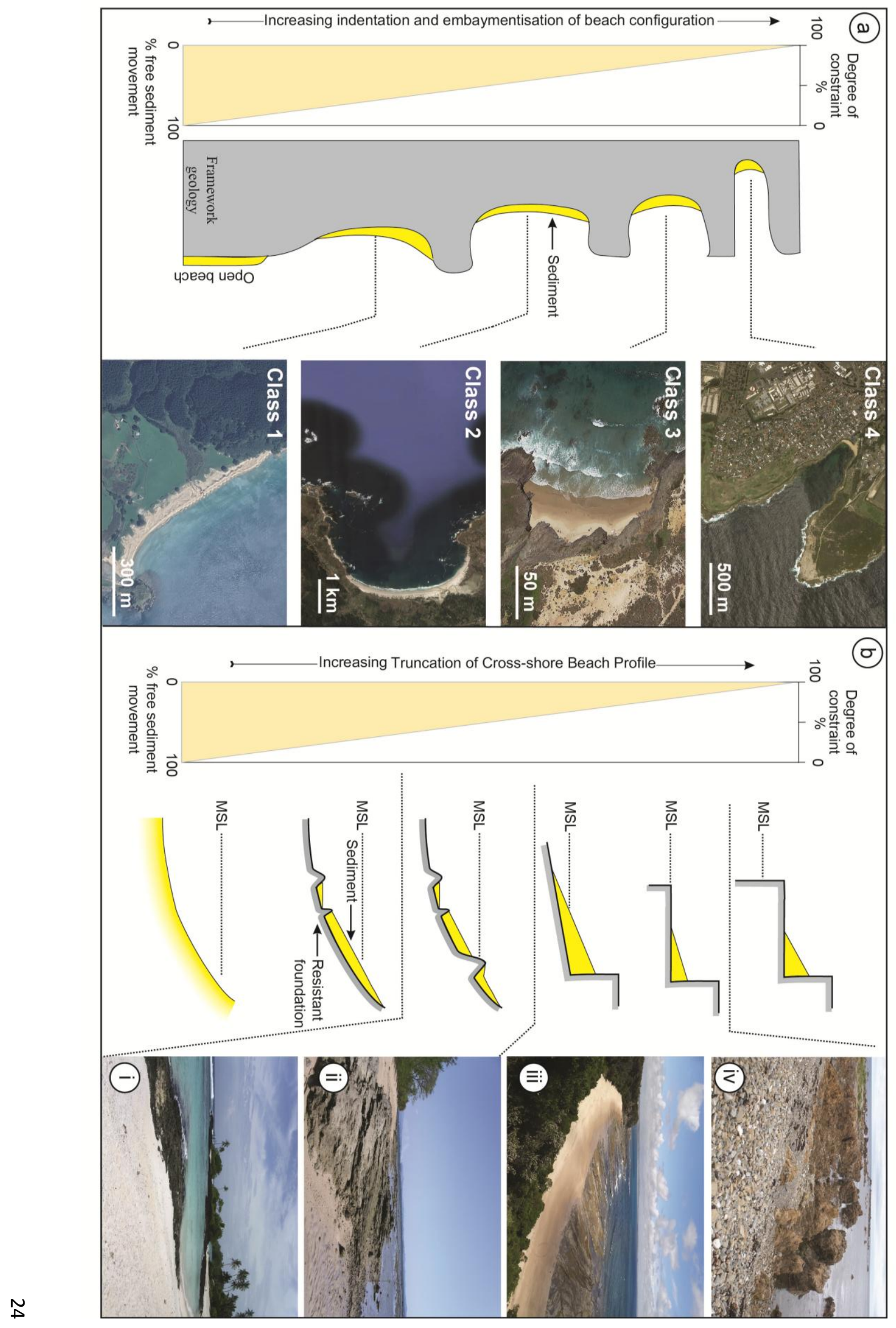


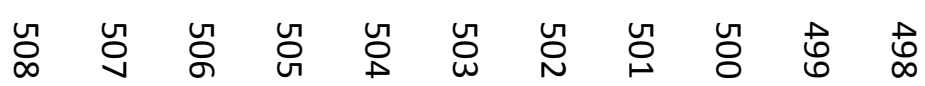

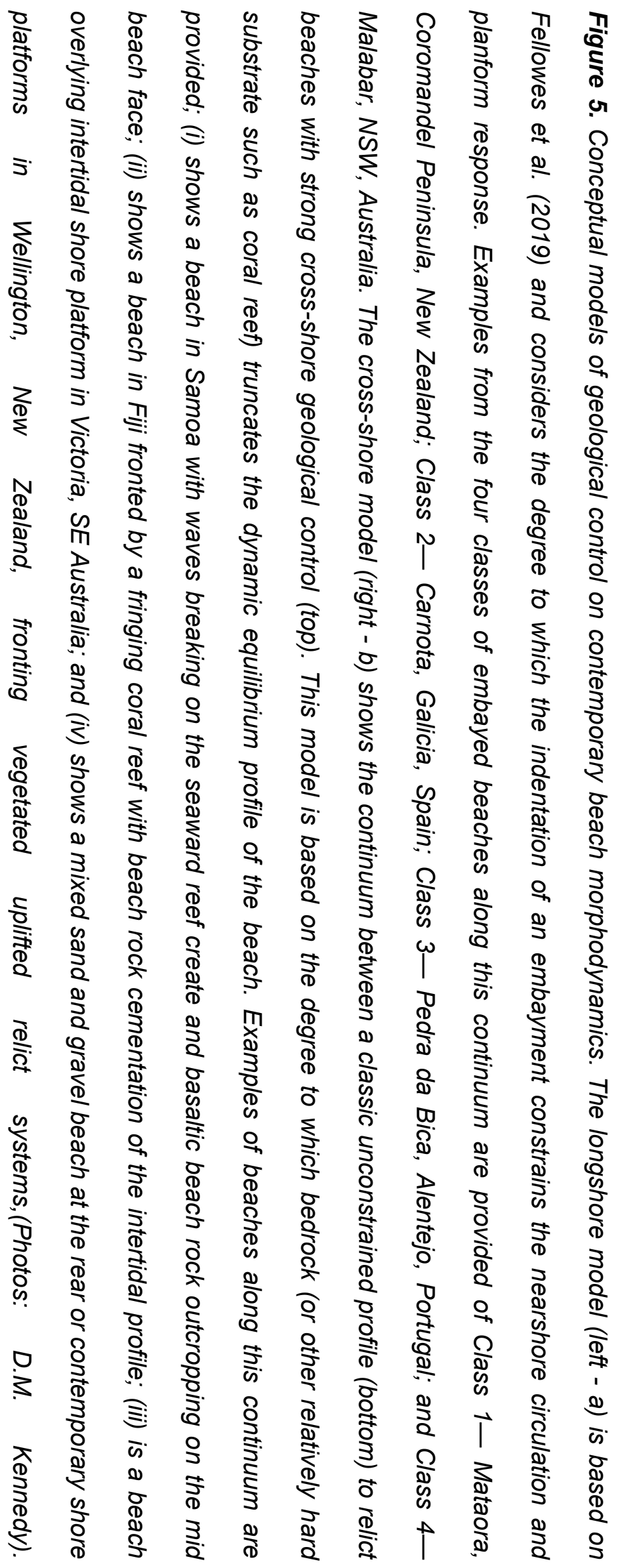


510 In addition to the longshore geology, the addition of cross-shore geological controls 511 completes setting the 3D accommodation space where beaches can accumulate. Cross512 shore geological control on beaches can occur in a variety of forms, from thick and semipermanent deposits atop of hard substrates; through thin, ephemeral veneers over shore platforms (Trenhaile, 2004; Jackson et al., 2005; Doucette, 2009; Gallop et al., 2013; Marsters and Kennedy, 2014; Trenhaile, 2016). There have been several attempts to classify levels of geological control on cross-shore beach profiles. Short (2006) suggested that in addition to wave/tide-dominated and wave-modified beaches, there is also a distinct type that is influenced by intertidal rock flats and fringing coral reefs present in Australia. Jackson and Cooper (2009) later introduced a conceptual model of levels of beach geological control based on beaches on the Outer Ards Peninsula in Northern Ireland, ranging from unconstrained, through to semi- and highly-constrained, depending on how much the beach volume and profile mobility are affected by geology intruding into the natural beach profile. There remains a need therefore for a universal classification system for the cross-shore geological control of beaches. Therefore, here we propose a new conceptual model of levels of geological control on beach morphodynamics, based on the degree of profile truncation.

The model we present in Figure $5 \mathrm{~b}$ builds on the original model proposed by Jackson and Cooper (2009) and includes two extremes of beaches relative to the level of cross-shore geological control on beach profile activity. One end of the spectrum is occupied by unconstrained beaches with no cross-shore geological control (Jackson and Cooper, 2009), and which have a profile with free sediment movement from the wave base to the upper 532 (landward) limit of storm-wave influence (Short and Jackson, 2013). In such cases, beach morphology is only a function of interactions between the nature of sediments, sediment supply and the hydrodynamic environment (Wright and Thom, 1977; Short and Jackson, 2013). At the other end of the spectrum, the geomorphological evolution of relict geologically 
controlled beaches has removed them from the contemporary littoral zone, so that they are

537 now above the normal reach of waves and tides (Figure 5, example iv). In between these

538 two extremes, there are varying degrees of geological control. Such beaches actively respond to marine processes but they are not able to completely form a dynamic equilibrium profile as sediment supply is limited and rock outcrops at the surface. That is, their crossshore profile is interrupted by a relatively hard substrate at some position on the shoreface, i.e., between the landward limit of wave run-up and wave base (Cowell et al., 1999).

Geologically controlled beaches, can be found close to MSL on shore platforms, often at the cliff-platform junction such as along the Great Ocean Road in SE Australia (Kennedy and Milkins, 2015), Niue in the South Pacific Ocean (Marsters and Kennedy, 2014) or SE China (Chen et al., 2011) Such beaches correspond to the examples iii and iv in Figure 5. Here, most of the beach volume is found in the intertidal zone (Paris et al., 2011), yet they are still geologically controlled as the lower part of the intertidal profile is occupied by resistant shore platforms rather than loose sediment. At the opposite end of the spectrum, are beaches where only the uppermost part of the profile is present, with bedrock or a similar immovable substrate occupying the lower portions of the profile (Figure 5b, example iv) This part of the beach will only be active during high magnitude storm events, but can still evidence typical beach processes as longshore sediment grading (Green et al., 2016).

It is important to note that development of beaches in coral reef seas does not necessarily occur directly on a reef surface; it can be separated from the reef crest by a lagoon (Kennedy and Woodroffe, 2002) (e.g., Figure 5b, example i). The depth and width of the lagoon and its hydrodynamic environment will then determine the degree of geological control. For example, in the shallow lagoons of the Maldives (Kench and Brander, 2006; Kench et al., 2006), Lord Howe Island, Australia (Kennedy, 2003), Cancun, Mexico (Mulcahy et al., 2016) and Samoa (Figure 5b, example i), the wave base is located offshore on the surrounding reef rim, with active sediment movement occurring across the entire reef system. In deeper atoll lagoons, such as Kapingamarangi Atoll, Federated States of 
563 Micronesia, the beach profile is not constrained and extends as an entirely sandy surface 564 down to wave base (McKee et al., 1959).

565 At the extreme end of cross-shore geological control is when rocky outcrops are found only on the lowest parts of the beach profile (termed semi-constrained by Jackson and Cooper

567 (2009). Such examples are found worldwide, such as in Portugal (Loureiro et al., 2012b) and Ireland (Jackson et al., 2005), where bedrock has been lowered below the intertidal zone or resistant lithology is present in the subtidal zone that can resist erosive marine forces (Figure $5 b$, example ii). The southern coast of south Western Australia (WA) is an example where rocky outcrops that are initially shore attached progressively deepen and move further offshore as the coast becomes embayed. In such settings the degree of sediment movement is directly influenced by the degree of truncation to the beach profile (Gallop et al., 2011b;

574 Gallop et al., 2012, 2013). In some cases, the geologically controlled nature of the beaches 575 may only be observable with detailed inshore surveying. For example, in Victoria, SE 576 Australia, sandy beaches may be relatively sediment-rich in the swash zone under normal 577 conditions but at greater depths where waves shoal, bedrock dominates the profile (Figure 578 6). In this respect, while the upper parts of the beach reflect a classic beach-bar system, the entire profile would have cross-shore geological control during storm conditions when wave base is located on the rocky outcrops. The rocky and sandy sections also have largely identical slopes, and the sandy beach profile is not concave as would be expected based on

582 the equilibrium beach profile theory (Bruun, 1954; Dean, 1977, 1991), suggesting that the sandy beach has inherited its shape from the pre-existing rocky surface. Such systems have received scant attention in the literature. 


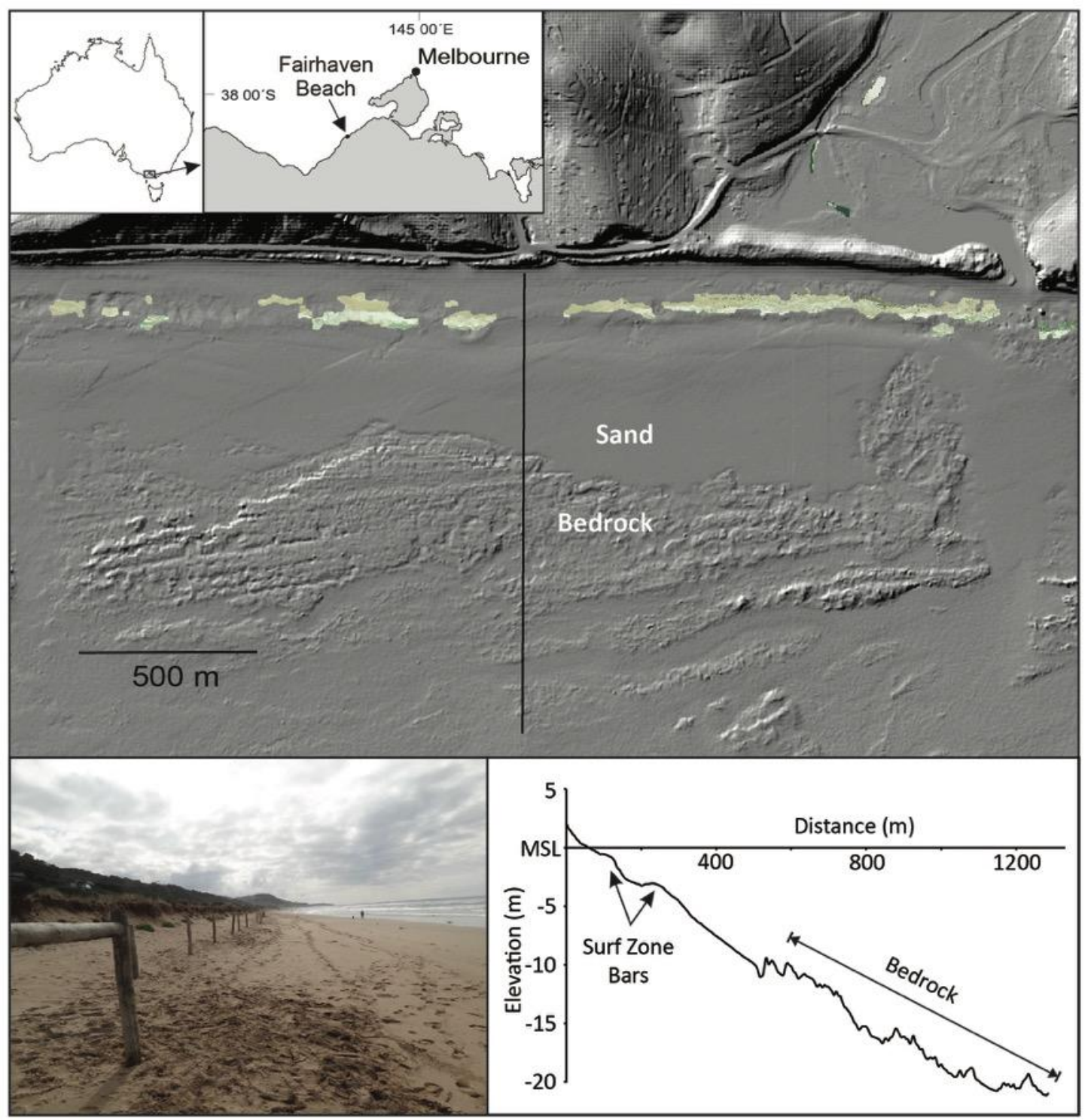

Figure 6. Bathymetric LiDAR of the nearshore of Fairhaven Beach, Victoria, SE Australia.

587 The toe of the sandy beach extends only to $10 \mathrm{~m}$ water depth, after which there is bare rock

588 down to the wave base. The presence of cross-shore geological control is not obvious when

589 observing only the subaerial beach face (photo: D.M. Kennedy).

\section{Management of geologically controlled beaches}

591 In addition to the many services provided by beaches themselves, these coastal systems also provide an important form of natural protection from the impacts of waves and sea level rise to coastal communities, infrastructure and habitats which lie behind. As shown by the

594 review above, our knowledge of geologically controlled beach morphodynamics and 
595 therefore how to manage them, is limited. There are few case studies on the management of 596 beach sediment erosion on geologically controlled beaches. Those that exist tend to apply 597 techniques that do not consider the complexity and variety of geologically controlled beach systems. For example, artificial reefs and offshore breakwaters have been put forward as mechanisms for controlling cross-shore beach erosion (Dean and Dalrymple, 2001), while perpendicular structures such as groins or artificial headlands are used with the aim of controlling longshore erosion and promote a stable beach planform (Silvester and Hsu, 1997). While such engineering techniques seem conceptually robust, they are based on a narrow consideration of the long-term apparent stability of geologically controlled beaches. They fail to consider the vast majority of characteristic morphodynamic responses of geologically controlled beaches that we highlight in this paper, such as alongshore nonuniformity in storm response, rip circulation and beach rotation. Because the morphodynamics of geologically controlled beaches are much more complex than assumed by existing beach engineering concepts, achieving a dynamic equilibrium with geological control is unfeasible with coastal engineering solutions that focus on one specific aspect (i.e., cross shore erosion or planform equilibrium) and disregard the complex cross and longshore morphodynamics.

Beach nourishment, reprofiling and redistribution are other possible methods to assist these beach systems provide continued coastal flood and erosion risk alleviation benefits to society. Some suggestions for applying these techniques to geologically controlled beaches are made here. First, when considering beach nourishment, it is important to distinguish between the apparent loss of nourished sediment due to beach rotation or the actual loss of sediment due to headland bypassing (i.e. leaky systems), which is likely to increase in nourished geologically controlled beaches. The adjustment of a nourished beach profile when there are cross-shore geological constraints is also likely to depart from theoretical models of cross-shore sediment redistribution used in coastal engineering (Muñoz-Perez et al., 2020). Scaling up to a local sediment cell, there is scant understanding of and limited 
622 modelling tools to predict the rates of sediment transport from geologically controlled 623 beaches to other coastal systems, or between these beaches (Naylor et al., 2016). For 624 example, a geologically controlled beach might be an important supply of sediment to a nearby spit (as in Westward Ho!, North Devon, UK), but we have limited understanding of the process and of how much geologically controlled beach material serves as a key source of sediment to an economically and socially valuable beach spit. Moreover, it is largely unclear how to account for spatial variations in geological controls to quantify beach nourishment volumes and costs, and how to include the effect of this variation on the beach morphodynamics and hence nourishment performance and longevity (Muñoz-Perez et al., 2020).

Management implications of sea level rise for geologically controlled beaches can also consider the changes in accommodation space by higher sea levels and the fact that geologically controlled beaches cannot retreat landwards according to a Brunn rule style (Bon de Sousa et al., 2018), as many are backed by rocky cliffs or seawalls/promenades on developed coasts. This will lead to "coastal squeeze" (Pontee, 2013) and potential modification of the beach profile steepness and morphodynamics, such as the potential for erosion of the beach via faster rates of longshore or cross-shore transport of material. For example, Brayne (2016) showed that in North Devon the alongshore difference in platform elevation can be used as a proxy for sea level rise impacts, showing that as sea level rises, wave energy delivery to beaches at the cliff-platform junction will increase causing the beaches to be steeper and higher.

Recent storm events have demonstrated that sandy beaches can be eroded so significantly during storm events that the underlying bedrock is exposed (see Section 3.2). This means that beaches can oscillate between behaving as an unconstrained sandy beach, and geologically controlled beach. Beach recovery will occur during the geologically controlled phase, which as discussed in this review, is a state for which we largely lack data-driven methods and models to apply to beach restoration. In addition to ecological and coastal 
defence implications, this also has economic implications, as these beaches are often highly

650 important for coastal tourism, and thus local economies (e.g. Bon de Sousa et al., 2018).

651 Conceptual and empirical models that can explain the shifts in beach type and their recovery

652 (or oscillation between beach types) and response to sea level rise, storminess and changes

653 in wave climate as well as sediment supply, are thus an important need.

654 Addressing this gap in our scientific knowledge of these systems and to develop improved

655 tools for coastal risk management of these beach systems is thus critical to support 656 geologically controlled beach management strategies and for evaluating their exposure to to 657 climate change risks. Of key importance for now, is for coastal geomorphologists, coastal 658 engineers and coastal managers to clearly communicate what geologically controlled sandy 659 beaches are and how they differ from well-studied and modelled, unconstrained sandy beaches. Crucially, it is important to articulate what this means for modelling and managing these systems, specifically to (1) highlight the poor applicability of the majority of existing morphodynamic parameterisations and models; and (2) advise managers on how best to assess, predict and manage geologically controlled beaches.

\section{Conclusions}

665 Geologically controlled beaches are a distinct beach type, and have their own unique morphodynamic processes that make them behave differently to unconstrained beaches. This review focused on bringing together the various naming conventions and studies of what geologically controlled beaches are, and focused on the morphology and morphodynamics of those composed of sand. In addition to sediment supply, key factors that determine where geologically controlled beaches form are determined by basement geology, both in terms of longshore accommodation, such as in the form of coastal embayments with

672 lateral headlands; and in the cross-shore dimension, particularly if there is a rock platform, 673 whose elevation and gradient also are important factors for determining if a beach can accumulate. Geologically controlled beaches can have striking variations in sediment 
coverage, where at times the underlying geology could be totally exposed with little beach sediment or only a thin veneer, through to relatively deep beaches that may have little interaction with the underlying bedrock. Many geologically controlled beaches are embayed within headlands, thus wave shadowing by headlands, sometimes enhanced by wave breaking and dissipation in areas of exposed rock or coral substrates, can result in strong alongshore gradients in wave energy which result in corresponding variations in beach morphology, morphodynamics and storm responses. Geologically controlled rip currents such as shadow rips and deflection rips are important features on embayed beaches, and cellular circulation and mega-rips can also occur. Finally, beach rotation is also an important process on many geologically controlled beaches as a result of the combined cross-shore and longshore gradients in wave energy and resulting beach morphological responses. To encompass the above processes, we present longshore and cross-shore models of geological beach control. In the longshore dimension, our model ranges from low geological control in the form of relatively shallow embayed beaches, through to highly embayed beaches, as indentation and embaymentisation have an important influence on the morphodynamic processes and determine if the beach sediment budget is closed or leaky. The cross-shore model is based on the degree of geological constraint on cross-shore sediment transport, from beaches with no cross-shore geological control through to relict geologically controlled beaches that are above the contemporary littoral zone. Further study is identified as a research priority to more clearly define why and how the morphodynamics of geologically controlled beaches differ from unconstrained beach systems. This knowledge is critical for revising sediment transport equations and morphodynamic models of beach evolution. Such data and process understanding are crucial to assist coastal managers in effective management of geologically controlled beach systems both now and under an uncertain future climate.

\section{Acknowledgements}


LAN appreciates the support of Prof. Viles for her doctoral research on ephemeral beaches

in Wales that is presented in this paper. SLG's contribution to this project received funding from the Australian Research Council (ARC) Discovery Project DP160102561. CL's contribution is developed in the framework of H2020 MSCA NEARControl project, which received funding from the European Commission under grant agreement no. 661342.

\section{References}

Alexandrakis, G., Ghionis, G., and Poulos, S., 2013, The effect of beach rock formation on the morphological evolution of a beach: The case study of an eastern Mediterranean Beach: Ammoudara, Greece: Journal of Coastal Research, v. SI69, p. 47-59.

Alonso, A., and Pagés, J. L., 2007, Stratigraphy of Late Pleistocene coastal deposits in Northern Spain: Journal of Iberian Geology, v. 33, no. 2, p. 207-220.

Alvarez-Ellacuria, A., Orfila, A., Olabarrieta, M., Gómez-pujol, L., Medina, R., and Tintoré, J., 2009, An alert system for beach hazard management in the Balearic Islands: Coastal Management, v. 37, no. 6, p. 569-584.

Antonio Henrique da Fontoura, K., Lindino Benedet, F., and Delamar, H. S., 2002, ShortTerm Beach Rotation Processes in Distinct Headland Bay Beach Systems: Journal of Coastal Research, v. 18, no. 3, p. 442-458.

Aragonés, L., López, I., Villacampa, Y., and Navarro-González, F. J., 2016, Using the Presence of Seagrass Posidonia oceanica to Model the Equilibrium Profile Parameter A of Sandy Beaches in Spain: Journal of Coastal Research, v. 33, no. 5, p. 1074-1085.

Basterretxea, G., Orfila, A., Jordi, A., Casas, B., Lynett, P., Liu, P. L. F., Duarte, C. M., and Tintoré, J., 2004, Seasonal dynamics of a microtidal pocket beach with Posidonia oceanica seabeds (Mallorca, Spain): Journal of Coastal Research, v. 20, no. 4 (204), p. $1155-1164$.

Beetham, E. P., and Kench, P. S., 2011, Field observations of infragravity waves and their behaviour on rock shore platforms: Earth Surface Processes and Landforms, v. 36, no. 14 , p. 1872-1888.

Benedetti, M. M., Haws, J. A., Funk, C. L., Daniels, J. M., Hesp, P. A., Bicho, N. F., Minckley, T. A., Ellwood, B. B., and Forman, S. L., 2009, Late Pleistocene raised beaches of coastal Estremadura, central Portugal: Quaternary Science Reviews, v. 28 , no. 27 , p. $3428-3447$.

Blackburn, G., Bond, R. D., and Clarke, A. R. P., 1967, Soil development in relation to stranded beach ridges of County Lowan, Victoria: CSIRO.

Blossier, B., Bryan, K. R., Daly, C. J., and Winter, C., 2017, Shore and bar cross-shore migration, rotation, and breathing processes at an embayed beach: Journal of Geophysical Research: Earth Surface, v. 122, no. 10, p. 1745-1770.

Bon de Sousa, L., Loureiro, C., and Ferreira, O., 2018, Morphological and economic impacts of rising sea levels on cliff-backed platform beaches in southern Portugal: Applied Geography, v. 99, p. 31-43.

Bosserelle, C., Haigh, I. D., Pattiaratchi, C., and Gallop, S., Simulation of perched beach accretion using Smoothed Particle Hydrodynamics, in Proceedings 20th Australasian Coastal and Ocean Engineering Conference 2011 and the 13th Australasian Port and Harbour Conference 2011, Coast and Ports 20112011 2011, p. 1-5.

Bowman, D., Guillén, J., López, L., and Pellegrino, V., 2009, Planview Geometry and morphological characteristics of pocket beaches on the Catalan coast (Spain): Geomorphology, v. 108, no. 3-4, p. 191-199. 
Brander, R. W., Kench, P. S., and Hart, D., 2004, Spatial and temporal variations in wave characteristics across a reef platform, Warraber Island, Torres Strait, Australia: Marine Geology, v. 207, no. 1, p. 169-184.

Brayne, R. P., 2016, The relationship between nearshore wave conditions and coarse clastic beach dynamics, PhD: Exeter University.

Bruun, P., 1954, Coast erosion and the development of beach profiles: Beach Erosion Board.

Bryan, K. R., Foster, R., and MacDonald, I., 2013, Beach rotation at two adjacent headlandenclosed beaches: Journal of Coastal Research, v. Special Issue 65, p. 2095-2100.

Bryan, K. R., Gallop, S. L., Van De Lageweg, W. I., and Coco, G., Observations of rip channels, sandbar-shoreline coupling and beach rotation at Tairua Beach, New Zealand, in Proceedings 19th Australasian Coastal and Ocean Engineering Conference 2009 and the 12th Australasian Port and Harbour Conference 2009, COASTS and PORTS 20092009 2009, p. 262-267.

Castelle, B., and Coco, G., 2012, The morphodynamics of rip channels on embayed beaches: Continental Shelf Research, v. 43, p. 10-23.

-, 2013, Surf zone flushing on embayed beaches: Geophysical Research Letters, v. 40, no. 10 , p. $2206-2210$.

Castelle, B., Scott, T., Brander, R. W., and McCarroll, R. J., 2016, Rip current types, circulation and hazard: Earth-Science Reviews, v. 163, p. 1-21.

Chen, B., Chen, Z., Stephenson, W., and Finlayson, B., 2011, Morphodynamics of a boulder beach, Putuo Island, SE China coast: The role of storms and typhoon: Marine Geology, v. 283, no. 1, p. 106-115.

Cleary, W. J., Riggs, S. R., Marcy, D. C., and Snyder, S. W., 1996, The influence of inherited geological framework upon a hardbottom-dominated shoreface on a high-energy shelf: Onslow Bay, North Carolina, USA: Geological Society, London, Special Publications, v. 117, no. 1, p. 249.

Cooper, J. A. G., 1991, Beachrock formation in low latitudes: implications for coastal evolutionary models: Marine Geology, v. 98, no. 1, p. 145-154.

Cooper, J. A. G., Green, A. N., and Loureiro, C., 2018, Geological constraints on mesoscale coastal barrier behaviour: Global and Planetary Change, v. 168, p. 15-34.

Cooper, N. J., and Pontee, N. I., 2006, Appraisal and evolution of the littoral 'sediment cell' concept in applied coastal management: Experiences from England and Wales: Ocean \& Coastal Management, v. 49, no. 7, p. 498-510.

Cowell, P. J., Hanslow, D. J., and Meleo, J. F., 1999, The shoreface, in Short, A. D., ed., Handbook of beach and shoreface morphodynamics: Chichester, John Wiley and Sons, p. 39-71.

Cowell, P. J., and Thom, B. G., 1994, Morphodynamics of coastal evolution, in Carter, R. W. G., and Woodroffe, C. D., eds., Coastal Evolution: Late Quaternary Shoreline Morphodynamics: Cambridge, Cambridge University Press, p. 33-86.

Daly, C. J., Bryan, K. R., and Winter, C., 2014, Wave energy distribution and morphological development in and around the shadow zone of an embayed beach: Coastal Engineering, v. 93, p. 40-54.

Davidson-Arnott, R. G. D., and Law, M. N., 1996, Measurement and Prediction of Long-Term Sediment Supply to Coastal Foredunes: Journal of Coastal Research, v. 12, no. 3, p. 654-663.

Dean, R. G., 1977, Equilibrium beach profiles: U.S. Atlantic and Gulf coasts: Department of Civil Engineering, University of Delaware.

-, 1991, Equilibrium Beach Profiles: Characteristics and Applications: Journal of Coastal Research, v. 7 , no. 1, p. 53-84.

Dean, R. G., Chen, R., and Browder, A. E., 1997, Full scale monitoring study of a submerged breakwater, Palm Beach, Florida, USA: Coastal Engineering, v. 29, no. 3, p. 291-315.

Dean, R. G., and Dalrymple, R. A., 2001, Coastal Processes with Engineering Applications, Cambridge, Cambridge University Press. 
Dickinson, W. R., 1999, Holocene Sea-Level Record on Funafuti and Potential Impact of Global Warming on Central Pacific Atolls: Quaternary Research, v. 51, no. 2, p. $124-$ 132.

Doucette, J. S., Photographic monitoring of erosion and accretion events on a platform beach, Cottesloe, Western Australia, in Proceedings 33rd IAHR Congress, Vancouver, 2009.

Eversole, D., and Fletcher, C. H., 2003, Longshore Sediment Transport Rates on a ReefFronted Beach: Field Data and Empirical Models Kaanapali Beach, Hawaii: Journal of Coastal Research, v. 19, no. 3, p. 649-663.

Feal-Pérez, A., Blanco-Chao, R., Ferro-Vázquez, C., Martínez-Cortizas, A., and CostaCasais, M., 2014, Late-Holocene storm imprint in a coastal sedimentary sequence (Northwest lberian coast): The Holocene, v. 24, no. 4, p. 477-488.

Fellowes, T. E., Vila-Concejo, A., and Gallop, S. L., 2019, Morphometric classification of swell-dominated embayed beaches: Marine Geology, v. 411, p. 78-87.

Ford, M. R., Becker, J. M., and Merrifield, M. A., 2013, Reef Flat Wave Processes and Excavation Pits: Observations and Implications for Majuro Atoll, Marshall Islands: Journal of Coastal Research, v. 29, no. 3, p. 545-554, 510.

Fox, W. T., and Davis, R. A. J., 1978, Seasonal variation in beach erosion and sedimentation on the Oregon coast: GSA Bulletin, v. 89, no. 10, p. 1541-1549.

Frihy, O. E., El Ganaini, M. A., El Sayed, W. R., and Iskander, M. M., 2004, The role of fringing coral reef in beach protection of Hurghada, Gulf of Suez, Red Sea of Egypt: Ecological Engineering, v. 22, no. 1, p. 17-25.

Gallop, S. L., Bosserelle, C., Eliot, I., and Pattiaratchi, C. B., 2012, The influence of limestone reefs on storm erosion and recovery of a perched beach: Continental Shelf Research, v. 47, p. 16-27.

-, 2013, The influence of coastal reefs on spatial variability in seasonal sand fluxes: Marine Geology, v. 344, p. 132-143.

Gallop, S. L., Bosserelle, C., Haigh, I. D., Wadey, M. P., Pattiaratchi, C. B., and Eliot, I., 2015a, The impact of temperate reefs on 34 years of shoreline and vegetation line stability at Yanchep, southwestern Australia and implications for coastal setback: Marine Geology, v. 369, p. 224-232.

Gallop, S. L., Bosserelle, C., Pattiaratchi, C., and Eliot, I., Form and function of natural and engineered perched beaches, in Proceedings 20th Australasian Coastal and Ocean Engineering Conference 2011 and the 13th Australasian Port and Harbour Conference 2011, COASTS and PORTS 20112011 2011a, p. 6-11.

-, 2011b, Rock topography causes spatial variation in the wave, current and beach response to sea breeze activity: Marine Geology, v. 290, no. 1-4, p. 29-40.

Gallop, S. L., Bryan, K. R., Coco, G., and Stephens, S. A., 2011c, Storm-driven changes in rip channel patterns on an embayed beach: Geomorphology, v. 127, no. 3-4, p. 179188.

Gallop, S. L., Bryan, K. R., Pitman, S. J., Ranasinghe, R., Sandwell, D. R., and Harrison, S. R., 2018, Rip current circulation and surf zone retention on a double barred beach: Marine Geology, v. 405, p. 12-22.

Gallop, S. L., Collins, M., Pattiaratchi, C. B., Eliot, M. J., Bosserelle, C., Ghisalberti, M., Collins, L. B., Eliot, I., Erftemeijer, P. L. A., Larcombe, P., Marigomez, I., Stul, T., and White, D. J., 2015b, Challenges in transferring knowledge between scales in coastal sediment dynamics: Front. Mar. Sci., v. 2.

George, A. D., Largier, L. J., Pasternack, B. G., Barnard, L. P., Storlazzi, D. C., and Erikson, H. L., 2019, Modeling Sediment Bypassing around Idealized Rocky Headlands: Journal of Marine Science and Engineering, v. 7, no. 2.

Gómez-Pujol, L., Orfila, A., Álvarez-Ellacuría, A., and Tintoré, J., 2011, Controls on sediment dynamics and medium-term morphological change in a barred microtidal beach (Cala Millor, Mallorca, Western Mediterranean): Geomorphology, v. 132, no. 3, p. 87-98. 
Gómez-Pujol, L., Orfila, A., Cañellas, B., Alvarez-Ellacuria, A., Méndez, F. J., Medina, R., and Tintoré, J., 2007, Morphodynamic classification of sandy beaches in low energetic marine environment: Marine Geology, v. 242, no. 4, p. 235-246.

Gómez-Pujol, L., Orfila, A., Morales-Márquez, V., Compa, M., Pereda, L., Fornós, J. J., and Tintoré, J., 2019, Beach systems of Balearic Islands: Nature, distribution and processes, in Morales, J. A., ed., The Spanish Coastal Systems: Dynamic Processes, Sediments and Management: Cham, Springer International Publishing, p. 269-287.

González, M., Medina, R., and Losada, M. A., 1999, Equilibrium beach profile model for perched beaches: Coastal Engineering, v. 36, no. 4, p. 343-357.

Green, A., Cooper, A., and Salzmann, L., 2016, Longshore Size Grading On A Boulder Beach: Journal of Sedimentary Research, v. 86, no. 10, p. 1123-1128.

Habel, S., Fletcher, C. H., Barbee, M., and Anderson, T. R., 2016, The influence of seasonal patterns on a beach nourishment project in a complex reef environment: Coastal Engineering, v. 116, p. 67-76.

Hanson, H., and Militello, A., 2005, Representation of non-erodible (hard) bottom in twodimensional morphology change models, Technical Note ERDC/CHL CHETN-IV-63.

Harley, M. D., Turner, I. L., and Short, A. D., 2015, New insights into embayed beach rotation: The importance of wave exposure and cross-shore processes: Journal of Geophysical Research: Earth Surface, v. 120, no. 8, p. 1470-1484.

Harley, M. D., Turner, I. L., Short, A. D., and Ranasinghe, R., 2011, A reevaluation of coastal embayment rotation: The dominance of cross-shore versus alongshore sediment transport processes, Collaroy-Narrabeen Beach, southeast Australia: Journal of Geophysical Research: Earth Surface, v. 116, no. F4.

Holman, R. A., Symonds, G., Thornton, E. B., and Ranasinghe, R., 2006, Rip spacing and persistence on an embayed beach: Journal of Geophysical Research: Oceans, v. 111, no. C1.

Horta, J., Oliveira, S., Moura, D., and Ferreira, Ó., 2018, Nearshore hydrodynamics at pocket beaches with contrasting wave exposure in southern Portugal: Estuarine, Coastal and Shelf Science, v. 204, p. 40-55.

Hsu, J., and Evans, C., 1989, Parabolic bay shapes and applications: Proceedings of the Institution of Civil Engineers, v. 87, no. 4, p. 557-570.

Hsu, J. R. C., Silvester, R., and Xia, Y.-M., 1989, Static Equilibrium Bays: New Relationships: Journal of Waterway, Port, Coastal, and Ocean Engineering, v. 115, no. 3, p. 285-298.

Huntley, D. J., Hutton, J. T., and Prescott, J. R., 1993, The stranded beach-dune sequence of south-east South Australia: A test of thermoluminescence dating, 0-800 ka: Quaternary Science Reviews, v. 12, no. 1, p. 1-20.

Inman, D. L., and Frautschy, J. D., Littoral processes and the development of shoreline, in Proceedings Proceedings of the Coastal Engineering Specialty Conference, Santa Barbara, California, 1966, ASCE, p. 511-536.

Jackson, D. W. T., and Cooper, J. A. G., 2009, Geological control on beach form: Accommodation space and contemporary dynamics: Journal of Coastal Research, $p$. 69-72.

Jackson, D. W. T., Cooper, J. A. G., and del Rio, L., 2005, Geological control of beach morphodynamic state: Marine Geology, v. 216, no. 4, p. 297-314.

Jacob, J., Gama, C., Salgado, R., Liu, J. T., and Silva, A., 2009, Shadowing effects on beach morphodynamics during storm events on Tróia-Sines embayed coast, southwest Portugal: Journal of Coastal Research, v. Special Issue 56, p. 73-77.

Karunarathna, H., and Tanimoto, K., 1995, Numerical experiments on low-frequency fluctuations on a submerged coastal reef: Coastal Engineering, v. 26, no. 3, p. 271289.

Kench, P. S., and Brander, R. W., 2006, Response of reef island shorelines to seasonal climate oscillations: South Maalhosmadulu atoll, Maldives: Journal of Geophysical Research, v. 111, no. F01001, p. doi:10.1029/2005JF000323. 
Kench, P. S., Brander, R. W., Parnell, K. E., and McLean, R. F., 2006, Wave energy gradients across a Maldivian atoll: Implications for island geomorphology: Geomorphology, v. 81, p. 1 - 17.

Kennedy, D. M., 2003, Surface lagoonal sediments at the environmental limits of reef growth, Lord Howe Island, Tasman Sea: Journal of Coastal Research, v. 19, p. 57 63.

Kennedy, D. M., 2015, Where is the seaward edge? A review and definition of shore platform morphology: Earth-Science Reviews, v. 147, p. 99-108.

-, 2016, The subtidal morphology of microtidal shore platforms and its implication for wave dynamics on rocky coasts: Geomorphology, v. 268, p. 146-158.

Kennedy, D. M., and Milkins, J., 2015, The formation of beaches on shore platforms in microtidal environments: Earth Surface Processes and Landforms, v. 30, p. 34 - 36.

Kennedy, D. M., and Woodroffe, C. D., 2002, Fringing reef growth and morphology: a review: Earth Science Reviews, v. 57, p. 255 - 277.

Kidson, C., and Wood, R., 1974, The Pleistocene stratigraphy of Barnstaple Bay: Proceedings of the Geologists' Association, v. 85, no. 2, p. 223-IN229.

Klein, A. H. F., and Menezes, J. T., 2001, Beach Morphodynamics and Profile Sequence for a Headland Bay Coast: Journal of Coastal Research, v. 17, no. 4, p. 812-835.

Larson, M., and Kraus, N. C., 2000, Representation of Non-Erodible (Hard) Bottoms in Beach Profile Change Modeling: Journal of Coastal Research, v. 16, no. 1, p. 1-14.

Long, J. W., and Özkan-Haller, T. H., 2005, Offshore controls on nearshore rip currents: Journal of Geophysical Research: Oceans, v. 110, no. C12.

Loureiro, C., and Ferreira, Ó., 2020, Chapter 24: Mechanisms and timescales of beach rotation, in Jackson, D. W. T., and Short, A. D., eds., Sandy beach: morphodynamics, Elsevier.

Loureiro, C., Ferreira, Ó., and Cooper, J. A. G., 2012a, Extreme erosion on high-energy embayed beaches: Influence of megarips and storm grouping: Geomorphology, v. 139-140, p. 155-171.

-, 2012b, Geologically constrained morphological variability and boundary effects on embayed beaches: Marine Geology, v. 329-331, p. 1-15.

-, 2013, Applicability of parametric beach morphodynamic state classification on embayed beaches: Marine Geology, v. 346, p. 153-164.

Mariño-Tapia, I., Enriquez, C., Silva, R., Mendoza-Baldwin, E., Escalante-Mancera, E., and Ruiz-Renteria, F., 2014, Comparative moprhodynamics between exposed and reef protected beaches under hurricane conditions: Coastal Engineering Proceedings; No 34 (2014): Proceedings of 34th Conference on Coastal Engineering, Seoul, Korea, 2014DO - 10.9753/icce.v34.sediment.55.

Marshall, R. J. E., and Stephenson, W. J., 2011, The morphodynamics of shore platforms in a micro-tidal setting: Interactions between waves and morphology: Marine Geology, v. 288 , no. 1 , p. $18-31$.

Marsters, T. H., and Kennedy, D. M., 2014, Beach development on an uplifted coral atoll: Niue, south west Pacific: Geomorphology, v. 222, p. 82-91.

Masselink, G., Scott, T., Poate, T., Russell, P., Davidson, M., and Conley, D., 2016, The extreme 2013/2014 winter storms: hydrodynamic forcing and coastal response along the southwest coast of England: Earth Surface Processes and Landforms, v. 41, no. 3, p. 378-391.

Masselink, G., and Short, A. D., 1993, The effect of tide range on beach morphodynamics and morphology: A conceptual beach model: Journal of Coastal Research, v. 9, no. 3, p. $785-800$.

McCarroll, R. J., Brander, R. W., Turner, I. L., and Leeuwen, B. V., 2016, Shoreface storm morphodynamics and mega-rip evolution at an embayed beach: Bondi Beach, NSW, Australia: Continental Shelf Research, v. 116, p. 74-88.

McCarroll, R. J., Brander, R. W., Turner, I. L., Power, H. E., and Mortlock, T. R., 2014, Lagrangian observations of circulation on an embayed beach with headland rip currents: Marine Geology, v. 355, p. 173-188. 
McKee, E. D., Chronic, J., and Leopold, E. B., 1959, Sedimentary belts in lagoon of Kapingamarangi Atoll: Bulletin of the American Association of Petroleum Geologists, v. 43, p. 501- 562.

McNinch, J. E., 2004, Geologic control in the nearshore: shore-oblique sandbars and shoreline erosional hotspots, Mid-Atlantic Bight, USA: Marine Geology, v. 211, no. 1, p. 121-141.

McSaveney, M. J., Graham, I. J., Begg, J. G., Beu, A. G., Hull, A. G., Kim, K., and Zondervan, A., 2006, Late Holocene uplift of beach ridges at Turakirae Head, south Wellington coast, New Zealand: New Zealand Journal of Geology and Geophysics, v. 49, p. $337-358$.

Milliman, J. D., 1974, Marine sedimentation, Berlin, Springer-Verlag.

Moreno, L., Negro, V., Garrote, L., Muñoz-Pérez, J. J., Santos López, J., and Dolores Esteban, M., 2018, An engineering method for the preliminary functional design of perched beaches. Theoretical approach: Journal of Coastal Research, v. SI85, p. 1261-1265.

Moschella, P. S., Abbiati, M., Åberg, P., Airoldi, L., Anderson, J. M., Bacchiocchi, F., Bulleri, F., Dinesen, G. E., Frost, M., Gacia, E., Granhag, L., Jonsson, P. R., Satta, M. P., Sundelöf, A., Thompson, R. C., and Hawkins, S. J., 2005, Low-crested coastal defence structures as artificial habitats for marine life: Using ecological criteria in design: Coastal Engineering, v. 52, no. 10, p. 1053-1071.

Mulcahy, N., Kennedy, D. M., and Blanchon, P., 2016, Hurricane-induced shoreline change and post-storm recovery: northeastern Yucatan Peninsula, Mexico: Journal of Coastal Research, p. 1192-1196.

Muñoz-Perez , J. J., Gallop, S. L., and Moreno, L. J., 2020, A comparison of beach nourishment methodology and performance at two fringing reef beaches in Waikiki (Hawaii, USA) and Cadiz (SW Spain): Journal of Marine Science and Engineering, v. 8 , no. 4, p. 266.

Muñoz-Pérez, J. J., and Medina, R., 2010, Comparison of long-, medium- and short-term variations of beach profiles with and without submerged geological control: Coastal Engineering, v. 57, no. 3, p. 241-251.

Muñoz-Pérez, J. J., Medina, R., and Tejedor, B., 2001, Evolution of longshore beach contour lines determined by E.O.F. method: Scientia Marina; Vol 65, No 4 (2001).

Muñoz-Pérez, J. J., Tejedor, L., and Medina, R., 1999, Equilibrium Beach Profile Model for Reef-Protected Beaches: Journal of Coastal Research, v. 15, no. 4, p. 950-957.

Naylor, L. A., 2001, Examining the contribution of biota to rock coast processes, Glamorgan Heritage Coast, South Wales, Unpubl. D.Phil Thesis.

Naylor, L. A., Stephenson, W. J., Smith, H. C. M., Way, O., Mendelssohn, J., and Cowley, A., 2016, Geomorphological control on boulder transport and coastal erosion before, during and after an extreme extra-tropical cyclone: Earth Surface Processes and Landforms, v. 41, no. 5, p. 685-700.

Naylor, L. A., and Viles, H. A., 2000, A temperate reef builder: an evaluation of the growth, morphology and composition of Sabellaria alveolata (L.) colonies on carbonate platforms in South Wales: Geological Society, London, Special Publications, v. 178, no. 1, p. 9-19.

Ogawa, H., Kench, P., and Dickson, M., 2012, Field Measurements of Wave Characteristics on a Near-Horizontal Shore Platform, Mahia Peninsula, North Island, New Zealand: Geographical Research, v. 50, no. 2, p. 179-192.

Ojeda, E., and Guillén, J., 2008, Shoreline dynamics and beach rotation of artificial embayed beaches: Marine Geology, v. 253, no. 1, p. 51-62.

Olson, D., Kennedy, D. M., Dawe, I., and Calder, M., 2012, Decadal-scale gravel beach evolution on a tectonically-uplifting coast: Wellington, New Zealand: Earth Surface Processes and Landforms, v. 37, p. $1133-1141$.

Paris, R., Naylor, L. A., and Stephenson, W. J., 2011, Boulders as a signature of storms on rock coasts: Marine Geology, v. 283, p. 1 - 11. 
Pattiaratchi, C., Olsson, D., Hetzel, Y., and Lowe, R., 2009, Wave-driven circulation patterns in the lee of groynes: Continental Shelf Research, v. 29, no. 16, p. 1961-1974.

Payo, A., and Muñoz-Perez, J. J., 2013, Discussion of Ford, M.R.; Becker, J.M., and Merrifield, M.A. 2013. Reef Flat Wave Processes and Excavation Pits: Observations and Implications for Majuro Atoll, Marshall Islands. Journal of Coastal Research, 29(3), 545-554: Journal of Coastal Research, p. 1236-1242.

Péquignet, A. C. N., Becker, J. M., Merrifield, M. A., and Aucan, J., 2009, Forcing of resonant modes on a fringing reef during tropical storm Man-Yi: Geophysical Research Letters, v. 36, no. 3.

Piazza, B. P., Banks, P. D., and La Peyre, M. K., 2005, The potential for created oyster shell reefs as a sustainable shoreline protection strategy in Louisiana: Restoration Ecology, v. 13, no. 3, p. 499-506.

Pilkey, O. H., Young, R. S., Riggs, S. R., Smith, A. W. S., Huiyan, W., and Walter, D. P., 1993, The Concept of Shoreface Profile of Equilibrium: A Critical Review: Journal of Coastal Research, v. 9, no. 1, p. 255-278.

Pontee, N., 2013, Defining coastal squeeze: A discussion: Ocean \& Coastal Management, v. 84, p. 204-207.

Ranasinghe, R., McLoughlin, R., Short, A., and Symonds, G., 2004, The Southern Oscillation Index, wave climate, and beach rotation: Marine Geology, v. 204, no. 3, p. 273-287.

Ranasinghe, R., Turner, I. L., and Symonds, G., 2006, Shoreline response to multi-functional artificial surfing reefs: A numerical and physical modelling study: Coastal Engineering, v. 53, no. 7, p. 589-611.

Rey, D., Rubio, B., Bernabeu, A. M., and Vilas, F., 2004, Formation, exposure, and evolution of a high-latitude beachrock in the intertidal zone of the Corrubedo complex (Ria de Arousa, Galicia, NW Spain): Sedimentary Geology, v. 169, no. 1, p. 93-105.

Riggs, S. R., Cleary, W. J., and Snyder, S. W., 1995, Influence of inherited geologic framework on barrier shoreface morphology and dynamics: Marine Geology, v. 126, no. 1, p. 213-234.

Ruiz de Alegria-Arzaburu, A., Mariño-Tapia, I., Enriquez, C., Silva, R., and González-Leija, M., 2013, The role of fringing coral reefs on beach morphodynamics: Geomorphology, v. 198, p. 69-83.

Russell, R. J., 1959, Caribbean beach rock observation: Zeitschrift für Geomorphologie, v. 3, p. 227-236.

Sanderson, P. G., 2000, A comparison of reef-protected environments in -Western Australia: the central west and Ningaloo coasts: Earth Surface Processes and Landforms, v. 25 , no. 4, p. 397-419.

Scott, T., Austin, M., Masselink, G., and Russell, P., 2016, Dynamics of rip currents associated with groynes - field measurements, modelling and implications for beach safety: Coastal Engineering, v. 107, p. 53-69.

Shand, T., Shand, R., Reinen-Hamill, R., Carley, J., and Cox, R., A review of shoreline response models to changes in sea level, in Proceedings Australasian Coasts and Ports Conference, Sydney, 2013.

Short, A. D., 1985, Rip-current type, spacing and persistence, Narrabeen Beach, Australia: Marine Geology, v. 65, no. 1, p. 47-71.

Short, A. D., 2006, Australian beach systems - Nature and distribution: Journal of Coastal Research, v. 22, no. 1, p. 11-27.

Short, A. D., 2007, Australian Rip Systems - Friend or Foe?: Journal of Coastal Research, p. 7-11.

Short, A. D., 2010, Role of geological inheritance in Australian beach morphodynamics: Coastal Engineering, v. 57, no. 2, p. 92-97.

Short, A. D., and Aagaard, T., 1993, Single and multi-bar beach change models: Journal of Coastal Research, v. 15, p. 141 - 157.

Short, A. D., and Hesp, P. A., 1982, Wave, beach and dune interactions in southeastern Australia: Marine Geology, v. 48, no. 3, p. 259-284. 
Short, A. D., and Jackson, D. W. T., 2013, Beach morphodynamics, in Shroder, J. F., ed., Treatise on Geomorphology, Volume 10: San Diego, Academic Press, p. 106-129.

Short, A. D., and Masselink, G., 1999, Embayed and structurally controlled beaches, in Short, A. D., ed., Handbook of beach and shoreface morphodynamics, John Wiley and Sons, p. 230-250.

Short, A. D., and Trembanis, A. C., 2004, Decadal Scale Patterns in Beach Oscillation and Rotation Narrabeen Beach, Australia: Time Series, PCA and Wavelet Analysis: Journal of Coastal Research, v. 20, no. 2, p. 523-532.

Silvester, R., and Hsu, J. R. C., 1997, Coastal Stabilization, Singapore, World Scientific Publishing.

Sprigg, R. C., 1979, Stranded and submerged sea-beach systems of southeast South Australia and the aeolian desert cycle: Sedimentary Geology, v. 22, no. 1, p. 53-96.

Stephenson, W. J., 2000, Shore platforms: a neglected coastal feature?: Progress in Physical Geography: Earth and Environment, v. 24, no. 3, p. 311-327.

Sunamura, T., 1989, Sandy beach geomorphology elucidated by laboratory modeling, in Lakhan, V. C., and Trenhaile, A. S., eds., Coastal Modeling: Techniques and Applications: Amsterdam, Elsevier, p. 159-213.

Syvitski, J. P. M., Vörösmarty, C. J., Kettner, A. J., and Green, P., 2005, Impact of humans on the flux of terrestrial sediment to the global coastal ocean: Science, v. 308, no. 5720 , p. 376.

Taborda, R., and Ribeiro, M. A., 2015, A simple model to estimate the impact of sea-level rise on platform beaches: Geomorphology, v. 234, p. 204-210.

Taebi, S., Lowe, R. J., Pattiaratchi, C. B., Ivey, G. N., Symonds, G., and Brinkman, R., 2011, Nearshore circulation in a tropical fringing reef system: Journal of Geophysical Research: Oceans, v. 116, no. C2.

Tamura, T., Murakami, F., Nanayama, F., Watanabe, K., and Saito, Y., 2008, Groundpenetrating radar profiles of Holocene raised-beach deposits in the Kujukuri strand plain, Pacific coast of eastern Japan: Marine Geology, v. 248, no. 1-2, p. 11-27.

Thom, B. G., 1989, Global Climatic Change: Issues for the Australian Coastal Zone. Prime Minister's Science Council: Australian Government Printing Service Press.

Thom, B. G., Eliot, I., Eliot, M., Harvey, N., Rissik, D., Sharples, C., Short, A. D., and Woodroffe, C. D., 2018, National sediment compartment framework for Australian coastal management: Ocean \& Coastal Management, v. 154, p. 103-120.

Trenhaile, A., 2016, Rocky coasts - their role as depositional environments: Earth-Science Reviews, v. 159, p. 1-13.

Trenhaile, A. S., 2004, Modeling the accumulation and dynamics of beaches on shore platforms: Marine Geology, v. 206, p. 55 - 72.

-, 2005, Modelling the effect of waves, weathering and beach development on shore platform development: Earth Surface Processes and Landforms, v. 30, p. 613 - 634.

Trenhaile, A. S., 2018, Modelling the effect of rising sea level on beaches with resistant foundations: Marine Geology, v. 395, p. 1-13.

Trenhaile, A. S., and Layzell, M. G. J., 1981, Shore platform morphology and the tidal duration factor: Transactions of the Institute of British Geographers, v. 6, p. 82 - 102.

Turki, I., Medina, R., Gonzalez, M., and Coco, G., 2013, Natural variability of shoreline position: Observations at three pocket beaches: Marine Geology, v. 338, p. 76-89.

US Army Corps of Engineers, 1984, Shore protection manual: Coastal Engineering Research Center.

Vousdoukas, M. I., Velegrakis, A. F., and Karambas, T. V., 2009, Morphology and sedimentology of a microtidal beach with beachrocks: Vatera, Lesbos, NE Mediterranean: Continental Shelf Research, v. 29, no. 16, p. 1937-1947.

Vousdoukas, M. I., Velegrakis, A. F., Paul, M., Dimitriadis, C., Makrykosta, E., and Koutsoubas, D., 2012, Field observations and modeling of wave attenuation over colonized beachrocks: Continental Shelf Research, v. 48, p. 100-109. 
Vousdoukas, M. I., Velegrakis, A. F., and Plomaritis, T. A., 2007, Beachrock occurrence, characteristics, formation mechanisms and impacts: Earth Science Reviews, v. 85, p. $23-46$.

Walkden, M. J. A., and Hall, J. W., 2005, A predictive Mesoscale model of the erosion and profile development of soft rock shores: Coastal Engineering, v. 52, no. 6, p. 535563.

Winter, G., Lowe, R. J., Symonds, G., Hansen, J. E., and van Dongeren, A. R., 2017, Standing infragravity waves over an alongshore irregular rocky bathymetry: Journal of Geophysical Research: Oceans, v. 122, no. 6, p. 4868-4885.

Wright, L. D., and Short, A. D., 1984, Morphodynamic variability of surf zones and beaches: A synthesis: Marine Geology, v. 56, no. 1, p. 93-118.

Wright, L. D., Short, A. D., and Green, M. O., 1985, Short-term changes in the morphodynamic states of beaches and surf zones: An empirical predictive model: Marine Geology, v. 62, no. 3, p. 339-364.

Wright, L. D., and Thom, B. G., 1977, Coastal depositional landforms: A Morphodynamic approach: Progress in Physical Geography, v. 1, p. 412-469.

Young, I. R., 1989, Wave transformation over coral reefs: Journal of Geophysical Research: Oceans, v. 94, no. C7, p. 9779-9789. 